\title{
Source identification and budget analysis on elevated levels of formaldehyde within the ship plumes: a ship-plume photochemical/dynamic model analysis
}

\author{
C. H. Song ${ }^{1}$, H. S. Kim ${ }^{1}$, R. von Glasow ${ }^{2}$, P. Brimblecombe ${ }^{2}$, J. Kim ${ }^{3}$, R. J. Park ${ }^{4}$, J. H. Woo ${ }^{5}$, and Y. H. Kim ${ }^{1}$ \\ ${ }^{1}$ School of Environmental Science and Engineering, Gwangju Institute of Science and Technology (GIST), Gwangju, \\ 500-712, Korea \\ ${ }^{2}$ School of Environmental Sciences, University of East Anglia, Norwich, NR4 7TJ, UK \\ ${ }^{3}$ Department of Atmospheric Sciences, Yonsei University, Seoul, 120-749, Korea \\ ${ }^{4}$ School of Environmental Sciences, Seoul National University, Seoul, 151-742, Korea \\ ${ }^{5}$ Department of Advanced Technology Fusion, Konkuk University, Seoul, 143-701, Korea
}

Received: 4 May 2010 - Published in Atmos. Chem. Phys. Discuss.: 23 June 2010

Revised: 23 October 2010 - Accepted: 25 October 2010 - Published: 15 December 2010

\begin{abstract}
Elevated levels of formaldehyde (HCHO) along the ship corridors have been observed by satellite sensors, such as ESA/ERS-2 GOME (Global Ozone Monitoring Experiment), and were also simulated by global 3-D chemistrytransport models. In this study, three likely sources of the elevated HCHO levels in the ship plumes as well as their contributions to the elevated $\mathrm{HCHO}$ levels (budget) were investigated using a newly-developed ship-plume photochemical/dynamic model: (1) primary $\mathrm{HCHO}$ emission from ships; (2) secondary $\mathrm{HCHO}$ production via the atmospheric oxidation of non-methane volatile organic compounds (NMVOCs) emitted from ships; and (3) atmospheric oxidation of $\mathrm{CH}_{4}$ within the ship plumes. For this ship-plume modelling study, the ITCT 2K2 (Intercontinental Transport and Chemical Transformation 2002) ship-plume experiment, which was carried out about $100 \mathrm{~km}$ off the coast of California on 8 May 2002 (11:00 local standard time), was chosen as a base study case because it is the best defined in terms of (1) meteorological data, (2) in-plume chemical composition, and (3) background chemical composition. From multiple shipplume model simulations for the ITCT $2 \mathrm{~K} 2$ ship-plume experiment case, $\mathrm{CH}_{4}$ oxidation by elevated levels of in-plume $\mathrm{OH}$ radicals was found to be the main factor responsible for the elevated levels of HCHO in the ITCT $2 \mathrm{~K} 2$ ship-plume. More than $\sim 88 \%$ of the HCHO for the ITCT $2 \mathrm{~K} 2$ ship-plume is produced by this atmospheric chemical process, except in
\end{abstract}

Correspondence to: C. H. Song (chsong@gist.ac.kr) the areas close to the ship stacks where the main source of the elevated $\mathrm{HCHO}$ levels would be primary $\mathrm{HCHO}$ from the ships (due to the deactivation of $\mathrm{CH}_{4}$ oxidation from the depletion of in-plume $\mathrm{OH}$ radicals). Because of active $\mathrm{CH}_{4} \mathrm{Ox}-$ idation by $\mathrm{OH}$ radicals, the instantaneous chemical lifetime of $\mathrm{CH}_{4}\left(\tau_{\mathrm{CH}_{4}}\right)$ decreased to $\sim 0.45 \mathrm{yr}$ inside the ship plume, which is in contrast to $\tau_{\mathrm{CH}_{4}}$ of $\sim 1.1 \mathrm{yr}$ in the background (up to $\sim 41 \%$ decrease) for the ITCT $2 \mathrm{~K} 2$ ship-plume case. A variety of likely ship-plume situations at three different latitudinal locations within the global ship corridors was also studied to determine the enhancements in the HCHO levels in the marine boundary layer (MBL) influenced by ship emissions. It was found that the ship-plume HCHO levels could be 19.9-424.9 pptv higher than the background $\mathrm{HCHO}$ levels depending on the latitudinal locations of the ship plumes (i.e., intensity of solar radiation and temperature), MBL stability and $\mathrm{NO}_{\mathrm{x}}$ emission rates. On the other hand, NMVOC emissions from ships were not found to be a primary source of photochemical HCHO production inside ship plumes due to their rapid and individual dilution. However, the diluted NMVOCs would contribute to the $\mathrm{HCHO}$ productions in the background air.

\section{Introduction}

Recently, ship emissions have attracted increasing attention because it is becoming obvious that ship-emitted $\mathrm{NO}_{\mathrm{x}}, \mathrm{SO}_{2}$ and particles can perturb the atmospheric photochemical cycles and global radiation budget significantly in the marine

Published by Copernicus Publications on behalf of the European Geosciences Union. 
boundary layer (MBL) (Corbett and Fischbeck, 1997; Capaldo et al., 1999; Corbett and Fischbeck, 1999; Lawrence and Crutzen, 1999; Kasibhatla et al., 2000; Song et al., 2003a,b; Endresen et al., 2003; Eyring et al., 2007; Hoor et al., 2009; Kim et al., 2009). Until now, many detailed analyses of the impacts of ocean-going ship emissions on atmospheric MBL chemistry and the global radiation budget have been carried out in a range of aspects: (1) $\mathrm{O}_{3} / \mathrm{HO}_{\mathrm{x}} / \mathrm{NO}_{\mathrm{y}}$ photochemistry in the MBL (e.g., Lawrence and Crutzen, 1999; Endresen et al., 2003; Song et al., 2003a; von Glasow et al., 2003; Kim et al., 2009); (2) sulfur cycle in the MBL (e.g., Capaldo et al., 1999; Song et al., 2003b; Faloona, 2009); and (3) impacts on the global radiation budget (e.g., Capaldo et al., 1999; Endresen et al., 2003; Langley et al., 2010).

More recently, elevated levels of HCHO in heavy shiptraffic corridors (or large $\mathrm{HCHO}$ tropospheric columns over the oceans impacted by ship emissions) were detected by the ESA/ERS-2 GOME (Global Ozone Monitoring Experiment) sensor (Marbach et al., 2009). The elevated HCHO levels along the heavy ship-traffic corridors are fundamentally important because they can greatly perturb the atmospheric oxidation cycle (or $\mathrm{O}_{3} / \mathrm{HO}_{\mathrm{x}} / \mathrm{N}_{\mathrm{x}} \mathrm{O}_{\mathrm{y}}$ photochemistry) in the shipinfluenced MBL. In turn, the perturbed oxidation cycle can also affect the global radiation budget, for example, by possibly enhancing the $\mathrm{O}_{3}$ mixing ratios in the MBL. According to global chemistry-transport modelling (CTM) studies by Bey et al. (2001) and Lawrence et al. (2001), approximately $\sim 50 \%$ of the global $\mathrm{CH}_{4}$ chemical losses is removed within the planetary and marine boundary layers (PBL and MBL), even when ship $\mathrm{NO}_{\mathrm{x}}$ emissions are not considered. Therefore, the model-predicted fractions of global $\mathrm{CH}_{4}$ destruction in the MBL could be even higher if $\sim 21 \%$ of the anthropogenic global $\mathrm{NO}_{\mathrm{x}}$ emissions from ocean-going ships are considered (see Corbett and Koeher, 2003). Recently, Hoor et al. (2009), in their multiple global 3-D CTM ensemble study, also reported active $\mathrm{CH}_{4}$ destruction within the PBL and MBL. However, in their study, 3-D grid-based CTM simulations were carried out, which by-passed the complex and nonlinear ship-plume photochemistry. According to Song et al. (2003a) and von Glasow et al. (2003), by-passing the nonlinear ship-plume photochemistry can result in overestimated $\mathrm{O}_{3}, \mathrm{OH}$ and $\mathrm{NO}_{\mathrm{x}}$ mixing ratios in the 3-D grid-based CTM simulations. In this sense, the rates of $\mathrm{CH}_{4}$ destruction calculated by Hoor et al. (2009) could be overestimated. Overall, it is important to understand the complex ship-plume photochemistry in a ship-influenced MBL, using a sophisticatedly designed ship-plume photochemical/dynamic model.

Another issue related to the ship-plume photochemistry is the possible enhancement of the HCHO level in the MBL located at different latitudes. There have been some discussions of the HCHO levels (and enhancements) related to the uncertainty in tropospheric $\mathrm{HCHO}$ column retrieval from satellites over heavy ship traffic corridors (e.g., Marbach et al., 2009). In this numerical analysis of ship-plume photochemistry, attempts were made to investigate two scien- tific issues: (1) what is the main (or dominant) atmospheric $\mathrm{HCHO}$ generation process, and (2) how much can $\mathrm{HCHO}$ be generated or the HCHO mixing ratios be elevated above the background $\mathrm{HCHO}$ levels by the atmospheric $\mathrm{HCHO}$ generation processes within the ship plumes?

In order to explore these issues, first of all, three likely sources of the elevated HCHO levels in the ship plumes were assumed and then examined: (1) primary HCHO emission from ships; (2) secondary $\mathrm{HCHO}$ production via the atmospheric oxidation of non-methane volatile organic compounds (NMVOCs) emitted from ships; and (3) atmospheric oxidation of $\mathrm{CH}_{4}$ within the ship plumes. A ship-plume photochemical/dynamic model developed previously by Kim et al. (2009) was used to help answer these scientific questions. In addition, in terms of the ship-plume photochemical/dynamic model development and its applications, this is a companion study of Kim et al. (2009) with a particular focus on ship-plume HCHO. This study first discusses a ship-plume case from the Intercontinental Transport and Chemical Transformation 2002 (ITCT 2K2) campaign as a base study case (hereafter, called "ITCT 2K2 ship-plume case"). This case was chosen as a base study case, because it is the best defined in terms of (1) meteorological data, (2) in-plume chemical composition, and (3) background (outplume) chemical composition. Various likely ship-plume cases at different latitudinal locations of the global ship tracks (hereafter, these are called "constructed cases") were then explored. The impacts of the ship-plume photochemistry on the MBL photochemical cycles, global climate and marine eco-system in the global ship corridors are further discussed based on the discussions in this study.

\section{Model characteristics, evaluation and simulations}

UBoM 2K8 (Utility photochemical Box Model 2008) was used in this numerical modelling study. The UBoM $2 \mathrm{~K} 8$ model has evolved with three operational modes for atmospheric photochemical modelling: (1) Lagrangian backward/forward trajectory photochemical modelling (Song et al., 2007); (2) Eulerian photochemical modelling (Tuan, 2008); and (3) ship-plume photochemical/dynamic modelling (Song et al., 2003a, b; Kim et al., 2009). Although the UBoM $2 \mathrm{~K} 8$ model has three operational modes, the three modes share the same gas-phase photochemistry, heterogeneous reactions and aerosol physics and dynamics. Details of the model components can be found in the abovementioned references. In this study, the photochemical modelling mode for the ship-plumes was used.

\subsection{Ship-plume model description}

The details of the ship-plume modelling components of the UBoM 2K8 model were explained previously by Song et al. (2003a, b) and Kim et al. (2009) and are not repeated here. In brief, the model has two fundamental components to 
treat: (1) atmospheric thermo-chemical, photo-chemical and heterogeneous reactions; and (2) turbulent dispersion of air pollutants emitted from a ship. For the latter, a "Gaussianbased" scheme for considering the horizontal and vertical turbulent dispersions of primary pollutants, such as $\mathrm{SO}_{2}$ and $\mathrm{NO}_{\mathrm{x}}$, was adopted from the Offshore and Coastal Dispersion (OCD) model with some modifications (Hanna et al., 1985; Song et al., 2003a; Kim et al., 2009). In particular, several turbulent ship-plume dispersion schemes within the MBL were reviewed by Faloona (2009). According to his study, the parameterizations from the OCD model would be the best for accurately describing the turbulent dispersion of ship plumes within the remote MBL, which was confirmed by Kim et al. (2009) using the ITCT 2K2 shipplume case. For the former, a modified Lurmann gas-phase chemical mechanism was used, in which 255 atmospheric gas-phase reactions coupled to heterogeneous condensations and aerosol micro-physics were considered (Lurmann et al., 1986; Song et al., 2003b). In addition to the gas-phase photochemical reactions, several gas/aqueous-phase sulfur reactions/equilibria were included to examine the chemical fates of sulfur species within the MBL (Song et al., 2003b). The heterogeneous, gas-particle interactions between nitrate precursors, such as $\mathrm{N}_{2} \mathrm{O}_{5}, \mathrm{NO}_{3}$ and $\mathrm{HNO}_{3}$, and sea-salt aerosols were also considered with reaction probabilities of $0.02,0.01$ and 0.05, respectively (Kim et al., 2009).

Although this ship-plume photochemical/dynamic model has an obvious advantage in that it considers the ship-plume photochemistry and turbulent dispersion simultaneously, the model cannot be initialized without background (out-plume) composition data. The background composition can affect the ship-plume (in-plume) composition via an entrainment process and subsequent atmospheric reactions inside the ship plumes. This effect can be important, particularly when the background air is polluted. Moreover, not all the chemical species are actually measured in background air. In this study, a background Eulerian box model was run with the ship-plume photochemical/dynamic model using the datasets from the field observations and/or 3-D regional or global CTM simulations to provide a full set of time-varying background concentrations into the ship-plume model.

\subsection{Ship-plume model evaluation}

The full capability of the ship-plume photochemi$\mathrm{cal} /$ dynamic model was evaluated comprehensively using a dataset from the ITCT $2 \mathrm{~K} 2$ ship-plume measurements by comparing the model-predicted concentrations with the aircraft-measured ship-plume concentrations of $\mathrm{NO}_{\mathrm{x}}$, $\mathrm{NO}_{\mathrm{y}}, \mathrm{O}_{3}, \mathrm{HNO}_{3}$ and $\mathrm{H}_{2} \mathrm{SO}_{4}$ (Parrish et al., 2004; Kim et al., 2009). A further comparison of the ozone production efficiency (OPE) inside the ship plume was also made (Xuan et al., 2009). Figure 1 shows a schematic diagram of the airborne ship-plume experiment using NOAA WP-3D aircraft during the ITCT $2 \mathrm{~K} 2$ campaign, which was carried out approximately $100 \mathrm{~km}$ off the coast of California on 8 May 2002 (11:00 local standard time). The NOAA WP-3D aircraft traversed the ship-plume eight times from transects A to $\mathrm{H}$ at an angle of $59^{\circ}$ between the ship-plume centerline and the flight pathways. In Fig. $1, \mathrm{~A}^{-}$and $\mathrm{A}^{\circ}$ represent two imaginary transects where the ship-plume photochemistry near the ship stack is intended to be investigated. Kim et al. (2009) reported that the developed ship-plume photochemical/dynamic model could simulate the ship-plume composition successfully. This was confirmed again in Fig. 2 with further multiple sensitivity model runs, in which the $\mathrm{NO}_{\mathrm{x}}$ emission rates from the ship were varied over a range of 2.6-13.3 $\mathrm{g} \mathrm{s}^{-1}$, together with the primary NMVOC and $\mathrm{HCHO}$ emission rates (both the primary NMVOC and $\mathrm{HCHO}$ emission rates are discussed further in Sect. 2.3.1). As shown in Fig. 2, there are relatively good agreements between the model-simulated and observed concentrations of $\mathrm{NO}_{\mathrm{x}}, \mathrm{O}_{3}$ and $\mathrm{HNO}_{3}$. For this set of model validations, the concentrations of one primary pollutant $\left(\mathrm{NO}_{\mathrm{x}}\right)$ and two secondary species $\left(\mathrm{O}_{3}\right.$ and $\left.\mathrm{HNO}_{3}\right)$ were compared because the photochemistry of these three species is coupled closely with one another and is also related strongly to the production of $\mathrm{OH}$ radicals, which play a key role in $\mathrm{CH}_{4}$ and NMVOC oxidation reactions in the MBL. In Fig. 2, the model-simulated levels of $\mathrm{HNO}_{3}$ are larger than those observed by the aircraft at ship-plume transect A to D. In the ship-plume model simulations, the levels of $\mathrm{HNO}_{3}$ are controlled mainly by the reaction probability of $\mathrm{HNO}_{3}$ onto sea-salt particles $\left(\gamma_{\mathrm{HNO}_{3}, \mathrm{ss}}\right)$ (Kim et al., 2009). In these

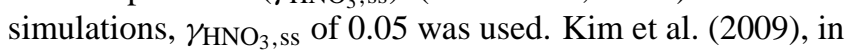
a sensitivity study, also reported that $\gamma_{\mathrm{HNO}_{3} \text {, ss }}$ could range between 0.05 and 0.1 . Therefore, the $\mathrm{HNO}_{3}$ levels would be lower if a large $\gamma_{\mathrm{HNO}_{3} \text {,ss }}$ value over the suggested range is used. In Fig. 2, the grey shadows represent the ranges of the model-simulated species concentrations under moderately stable MBL condition. Further details regarding the measurement uncertainties, selection of the MBL stability, and data analysis were discussed previously by Kim et al. (2009).

\subsection{Ship-plume model simulations}

This section examined the base study case first because it is well-defined in terms of meteorological and chemical information inside and around the ITCT 2K2 ship plume. Various likely ship-plume situations at different latitudinal locations of the global ship tracks (constructed case study) were then investigated.

\subsubsection{Estimation of the emission rates}

According to Chen et al. (2005), the ship being investigated in the base case was equipped with a $6707 \mathrm{KW}$ engine. With this power, the total rate of NMVOC emission from the ship can be estimated to be $0.93 \mathrm{~g} \mathrm{~s}^{-1}$ using the NMVOC 


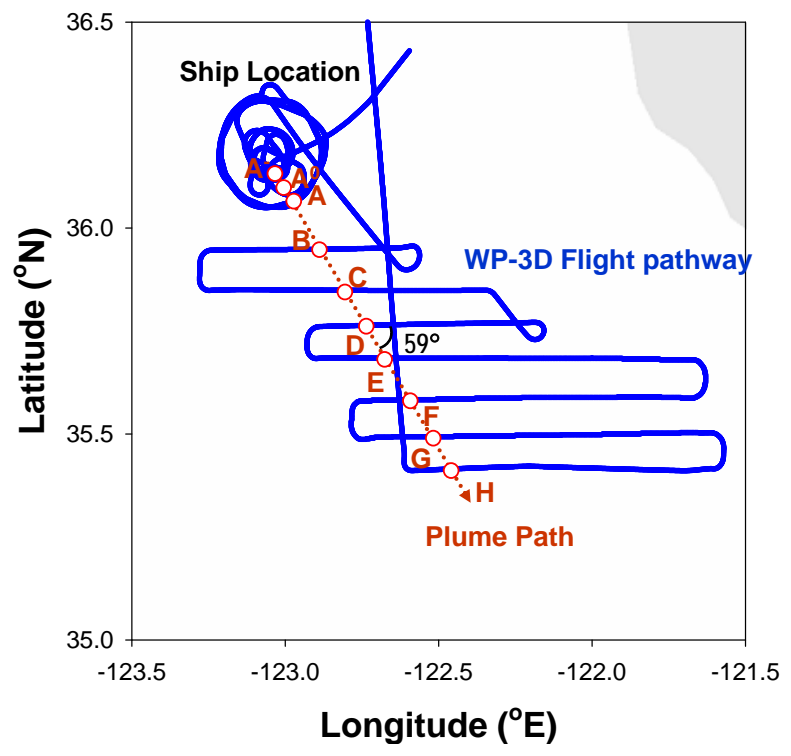

Fig. 1. Two imaginary ship-plume transects $\left(\mathrm{A}^{-}\right.$and $\left.\mathrm{A}^{\circ}\right)$ and eight actual ship-plume transects (A-H) made by a NOAA WP-3D flight during the ITCT $2 \mathrm{~K} 2$ campaign conducted $100 \mathrm{~km}$ off the California coast (Chen et al., 2005; Kim et al., 2009).

emission factor of $0.5 \mathrm{~g} \mathrm{KWh}^{-1}$ reported by European Commission Directorate General Environment and Entec UK Ltd. (2005; hereafter, abbreviated ECDGE \& Entec). On the other hand, the total NMVOC emission rate from the ship can also be estimated from a ratio of $\mathrm{NO}_{\mathrm{x}}$ to NMVOCs in the ship emissions. Again, according to ECDGE \& Entec (2005), the ratio was typically 29.6:1.0 ( $\mathrm{NO}_{\mathrm{x}}$ : NMVOCs) on a mass basis. Total NMVOC emission rates of $0.09-0.45 \mathrm{~g} \mathrm{~s}^{-1}$ were obtained from the estimated $\mathrm{NO}_{\mathrm{x}}$ emission rates from the ship (2.6 to $13.3 \mathrm{~g} \mathrm{~s}^{-1}$ ). From these estimations, the total NMVOC emission rate could range between $0.09 \mathrm{~g} \mathrm{~s}^{-1}$ and $0.93 \mathrm{~g} \mathrm{~s}^{-1}$. Although the estimated values have significant uncertainty, they appear to be consistent with the globallyaveraged ship NMVOC emission rate of $0.75 \mathrm{~g} \mathrm{~s}^{-1}$ estimated by Endresen et al. (2003). The estimated emission rates were also consistent with the ship emission rates reported recently from Buhaug et al. (2009). Buhaug et al. (2009) reported $\mathrm{NO}_{\mathrm{x}}$-to-NMVOC ratios of 35.4-37.5 and 21.3-23.3 for slow-speed diesel and medium-speed diesel engines, respectively. The ratio of 29.6 is intermediate between the values from the two different types of diesel engines.

Table 1 was constructed from the emission rates discussed above. In Table 1, the chemical speciation and fraction of NMVOCs emitted from the ship were determined from the ship-plume data reported by Cooper et al. (1996), EPA (2000), Endresen et al. (2003), ECDGE \& Entec (2005) and Houyoux (2005). The fraction of primary HCHO in the NMVOC emissions varies considerably from ship to ship, fuel-type, age of the ship, engine-speed, etc. HCHO fractions of $0.4-10.0 \%$ were reported based on the Lloyd
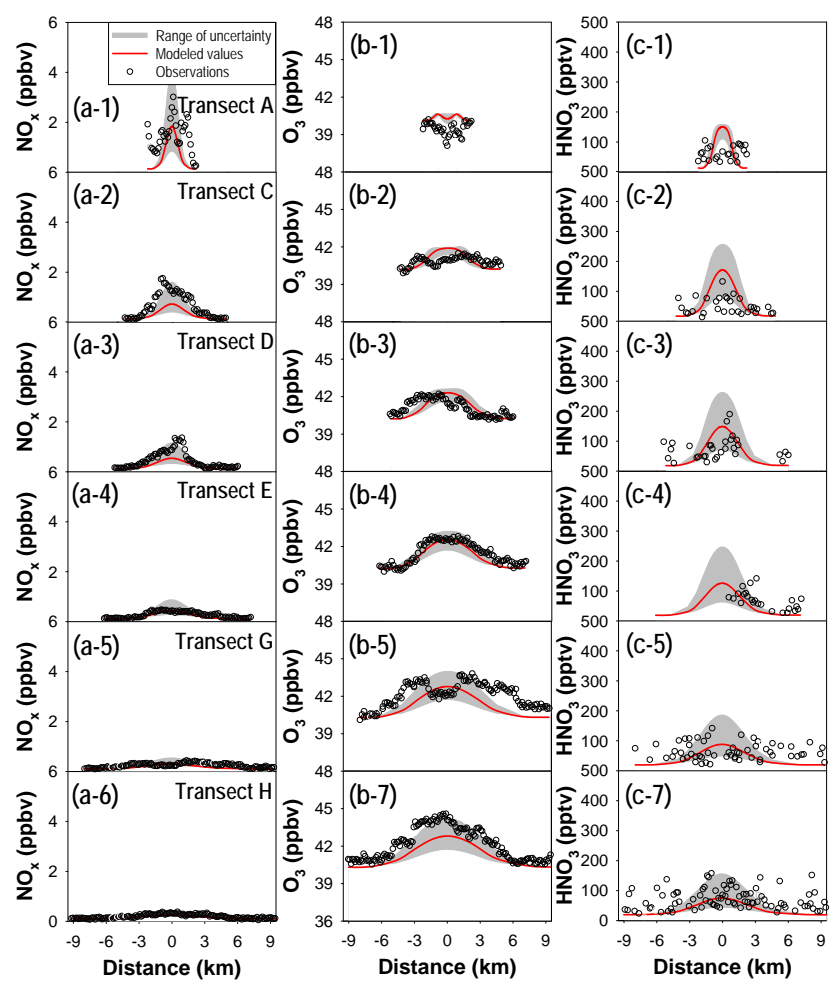

Fig. 2. Model validations at six transects for $\mathrm{NO}_{\mathrm{x}}, \mathrm{O}_{3}$ and $\mathrm{HNO}_{3}$. In the model simulations, the $\mathrm{NO}_{\mathrm{x}}$ emission rates from the ship were varied over a range of $2.6-13.3 \mathrm{~g} \mathrm{~s}^{-1}$, together with primary NMVOC and HCHO emissions under the moderately stable MBL condition. The grey-shaded areas represent the varying ranges of mixing ratios of the three species. The red-solid lines represent the mixing ratios simulated from the most-likely emission case.

Register (1995), EPA (2000), Houyoux (2005) and Marbach et al. (2009). Unless noted otherwise, the mid-point values from Table 1 were used (making their summation unity) in this numerical study of the ship-plume photochemical/dynamic modelling.

\subsubsection{Model simulations for base case}

As discussed by Kim et al. (2009), the ship-plume dispersion is governed primarily by the stability class of MBL. Based on the NOAA WP-3D aircraft measurements of the meteorological variables in/around the ship plume, Kim et al. (2009) suggested that the most likely stability class of the ship-going MBL would be moderately stable (E), with a possible change between moderately stable (E) and stable (F) MBL conditions.

In this ship-plume modelling study, a background photochemical box model was also run to consider the diurnal changes in HCHO mixing ratios in the background air using both the background meteorological conditions and chemical composition. This calculation was carried out by running the background photochemical box model until a 
Table 1. Estimated ranges of the NMVOC mass-fractions and emission rates from ships ${ }^{1}$.

\begin{tabular}{|c|c|}
\hline $\mathrm{NMVOCs}^{2}$ & Range of mass fraction \\
\hline Ethane & $0.001-0.024$ \\
\hline Ethene & $0.043-0.140$ \\
\hline Formaldehyde ${ }^{3}$ & $0.040-0.100$ \\
\hline Propane & $0.000-0.002$ \\
\hline Higher alkanes 4 & $0.161-0.619$ \\
\hline Higher alkenes 5 & $0.030-0.111$ \\
\hline Aromatics $^{6}$ & $0.099-0.277$ \\
\hline Benzene & $0.108-0.184$ \\
\hline Total NMVOC emission rate $(\mathrm{g} / \mathrm{s})^{7}$ & $0.09-0.93$ \\
\hline
\end{tabular}

${ }^{1}$ The mass fractions of NMVOCs species were estimated based on EPA (2002), Endersen et al. (2003), European Commission Directorate General Environment And Entec UK Limited (2005) and Houyoux (2005).

${ }^{2}$ Chemical speciation was based on Cooper et al. (1996).

3 The fraction of $\mathrm{HCHO}$ was assumed to be from $4 \%$ to $10 \%$ of the total NMVOC emissions (Houyoux, 2005; Marbach et al., 2009). 10\% is the upper-limit.

${ }^{4}$ Higher alkanes represent the lumped alkane species with carbon number $>4$.

${ }^{5}$ Higher alkenes represent the lumped alkene species with carbon number $>3$.

${ }^{6}$ Aromatics include branched benzene species such as toluene, xylene, stylene, etc.

${ }^{7}$ The total NMVOC emission rates were estimated based on Endersen et al. (2003) and Entec (2005).

pseudo steady-state in the background chemical composition had been reached. The background $\mathrm{HCHO}$ mixing ratios calculated were then mixed with the ship-plume volumes. By doing this, a discontinuity problem in $\mathrm{HCHO}$ mixing ratios, which typically occurs at the interface between the edge of the ship-plumes and the background air, can be avoided. With the exception of $\mathrm{HCHO}$, the fixed average concentrations measured by the NOAA WP-3D aircraft in the background air were used in the model simulations.

\subsubsection{Model simulations for constructed cases}

The ship-plume HCHO photochemistry was first investigated using the base-case ship plume (ITCT $2 \mathrm{~K} 2$ ship plume). The investigation is extended to various ship-track situations by applying the ship-plume photochemical/dynamic model to heavy ship-traffic corridors at three different latitudinal locations in the world. To accomplish this, thirty six possible scenarios are constructed by changing "three major variables": (1) latitude, (2) stability class, and (3) $\mathrm{NO}_{\mathrm{x}}$ emission rate. Table 2 lists the simulation conditions for the ship-plume photochemical/dynamic modelling. As shown in Table 2, the shiptrack situations at the three latitudes were considered in order to examine the enhancements in the HCHO levels (or the degree of activity of the HCHO-related photochemistry in the ship-going MBL): (1) tropical, (2) sub-tropical, and (3) midlatitude regions. The three latitudinal situations were constructed considering three busy ship-traffic corridors: (1) be- tween Sri Lanka and Sumatra ( $\left.5^{\circ} \mathrm{N} ; 90^{\circ} \mathrm{E}\right)$; (2) between Singapore and Taiwan $\left(27^{\circ} \mathrm{N} ; 127^{\circ} \mathrm{E}\right.$, near Taiwan, a polluted background situation); and (3) between Tokyo and San Francisco $\left(48^{\circ} \mathrm{N} ; 165^{\circ} \mathrm{E}\right.$, near Japan) over the western Pacific ocean (referring to Automated Mutual-assistance Vessel Rescue system (AMVER), http://www.amver.com/density.asp).

Unlike the base-case study, the constructed case studies are limited by insufficient information on the background conditions, which should be obtained from other 3D regional- or global-scale CTM simulations or from largescale campaign data. Therefore, to initialize the ship-plume model for the constructed case studies, the background composition was obtained from various measurements and global CTM simulations, such as NASA/GTE PEM-West A \& B and Trace-P campaigns and GEOS-CHEM modelling (Chin et al., 2000; de Gouw et al., 2001; Kamra et al., 2001; Arnold et al., 2009). The details are shown in Table 2.

One of the key issues of this study is $\mathrm{CH}_{4}$ and NMVOC oxidations. The $\mathrm{CH}_{4}$ and NMVOC oxidation rates are controlled mainly by the levels of $\mathrm{OH}$ radicals, which were found to be a function of the stability class of the MBL (Song et al., 2003a; Kim et al., 2009). Moreover, the $\mathrm{OH}$ radical mixing ratios are a strong function of other meteorological variables, such as solar radiation, relative humidity and temperature (Song et al., 2003a, b). Therefore, in order to consider these situations, the constructed cases were made by changing the factors that can affect the $\mathrm{OH}$ levels within the ship plumes. For example, the most active/vigorous ship-plume photochemistry would be expected in the "stable, tropical MBL" with large $\mathrm{NO}_{\mathrm{x}}$ emission rates, producing the highest $\mathrm{OH}$ levels.

In general situations, within the heavy ship-traffic MBL over the remote oceans, the stability class of the MBL frequently ranges from neutral (D) to stable (F) (cf. Frick and Hoppel, 2000; Song et al., 2003a). Therefore, three stability classes (instead of the two stability classes for the base case study) were considered in the ship-plume photochemi$\mathrm{cal} /$ dynamic modelling for the constructed cases at different latitudinal locations: (1) neutral (D); (2) moderately stable (E); and (3) stable (F) MBL stability classes. The results from the constructed case studies are discussed in Sect. 3.2.

\section{Results and discussions}

In this section, the budget of $\mathrm{HCHO}$ within the ITCT $2 \mathrm{~K} 2$ ship-plume was first examined because this ITCT 2K2 shipplume was analysed most thoroughly by Chen et al. (2005) and Kim et al. (2009) (Sect. 3.1). The ship-plume photochemical/dynamic model was then applied to locations at other latitudes to determine the possible enhancements in HCHO levels (or degree of activity of the HCHO-related photochemistry) within the global ship corridors (Sect. 3.2). 
Table 2. Simulation conditions for the constructed case studies ${ }^{1}$.

\begin{tabular}{|c|c|c|c|}
\hline Variable & Tropical & Sub-tropical & Mid-latitude \\
\hline Latitude $\left({ }^{\circ} \mathrm{N}\right)$ & 5 & 27 & 48 \\
\hline Longitude $\left({ }^{\circ} \mathrm{E}\right)$ & 90 & 127 & 165 \\
\hline Temperature $\left({ }^{\circ} \mathrm{C}\right)$ & 28 & 18 & 5 \\
\hline $\mathrm{NO}_{\mathrm{X}}(\mathrm{pptv})$ & 20.1 & 35.0 & 28.2 \\
\hline $\mathrm{SO}_{2}(\mathrm{pptv})^{2}$ & 35.2 & 26.4 & 11.3 \\
\hline $\mathrm{O}_{3}(\mathrm{ppbv})^{3}$ & 25.9 & 40.7 & 29.3 \\
\hline $\mathrm{CO}(\mathrm{ppbv})^{3}$ & 97.0 & 128.9 & 102.6 \\
\hline $\mathrm{C}_{2} \mathrm{H}_{6}(\mathrm{ppbv})^{3}$ & 0.7 & 0.9 & 1.0 \\
\hline $\mathrm{C}_{3} \mathrm{H}_{8}(\mathrm{pptv})^{3}$ & 258.2 & 608.6 & 451.7 \\
\hline $\operatorname{ALKA}(p p t v)^{3}$ & 58.1 & 395.7 & 214.0 \\
\hline ALKE (pptv) $)^{3}$ & 0.2 & 2.8 & 0.6 \\
\hline BENZ (pptv) & 110.1 & 115.3 & 90.0 \\
\hline $\mathrm{HCHO}(\mathrm{pptv})^{4}$ & 147.7 & 162.3 & 104.5 \\
\hline Isoprene (pptv) & $5.0^{5}$ & $4.0^{6}$ & $4.0^{5}$ \\
\hline DMS $(p p t v)^{2}$ & 65.0 & 40.2 & 220.0 \\
\hline $\mathrm{CH}_{4}(\mathrm{ppmv})$ & 1.80 & 1.80 & 1.82 \\
\hline$J\left(\mathrm{O}_{3}\right)\left(\mathrm{s}^{-1}\right)$ & $3.34 \times 10^{-5}$ & $2.58 \times 10^{-5}$ & $1.27 \times 10^{-5}$ \\
\hline$J(\mathrm{HCHO})\left(\mathrm{s}^{-1}\right)-\mathrm{a}^{7}$ & $3.13 \times 10^{-5}$ & $2.75 \times 10^{-5}$ & $1.90 \times 10^{-5}$ \\
\hline$J(\mathrm{HCHO})\left(\mathrm{s}^{-1}\right)-\mathrm{b}^{8}$ & $5.35 \times 10^{-5}$ & $4.91 \times 10^{-5}$ & $3.81 \times 10^{-5}$ \\
\hline $\begin{array}{l}\text { Aerosol surface den- } \\
\text { sity }\left(\mu \mathrm{m}^{2} / \mathrm{cm}^{3}\right)^{9}\end{array}$ & 42 & 42 & 42 \\
\hline Aerosol $\mathrm{pH}^{10}$ & 6.9 & 6.9 & 6.9 \\
\hline
\end{tabular}

\footnotetext{
${ }^{1}$ Background conditions for tropical, sub-tropical, and mid-latitude regions were obtained from INDOEX (de Gouw et al., 2001; Kamra et al., 2001; Wagner et al., 2002), TRACE-P, and PEM-West B airborne field campaigns (http://www-gte.larc.nasa.gov/pem/pemb_flt.htm).

2 Chin et al. (2000).

3 Annually-averaged mixing ratios obtained from GEOS-CHEM simulation for the year 2005 .

4 Annually-averaged values calculated from "Eulerian-mode" UBoM $2 \mathrm{~K} 8$ modeling with the simulation conditions given in Table 2. The minimum and maximum background HCHO mixing ratios are 97.8 pptv-195.8 pptv, 101.7 pptv-228.8 pptv, and 64.2 pptv-163.1 pptv in tropical, sub-tropical, and mid-latitude regions, respectively.

5 Wagner et al. (2002).

6 Arnold et al. (2009), annual average values.

${ }^{7} \mathrm{HCHO}+h v \rightarrow \mathrm{CHO}+\mathrm{H}$.

${ }^{8} \mathrm{HCHO}+h v \rightarrow \mathrm{CO}+\mathrm{H}_{2}$.

${ }^{9}$ Estimated, based on Jaenicke (1993).

${ }^{10}$ Assumed, based on Song et al. (2003b)
}

\subsection{Base-case study}

As mentioned in Sect. 1, the following three possible sources of the elevated $\mathrm{HCHO}$ levels were considered in this numerical study: (1) primary $\mathrm{HCHO}$ emission from ships; (2) secondary HCHO production via atmospheric oxidation of NMVOCs emitted from ships; and (3) atmospheric oxidations of $\mathrm{CH}_{4}$ within the ship plumes. Of these three possible sources, the $\mathrm{CH}_{4}$ oxidation reactions need to be explained further. In theory, two atmospheric reactions could initiate photochemical $\mathrm{HCHO}$ production via the atmospheric $\mathrm{CH}_{4}$ oxidation: (1) $\mathrm{CH}_{4}+\mathrm{OH}$ (Reaction (R1) in Table 3) and (2) $\mathrm{CH}_{4}+\mathrm{O}\left({ }^{1} \mathrm{D}\right)$ (with two reaction pathways, refer to Reactions (R2) and (R3) in Table 3). Of these three reactions, the latter two would be of secondary importance because $\mathrm{O}\left({ }^{1} \mathrm{D}\right)$ radicals react mainly with the abundant $\mathrm{N}_{2}$ and $\mathrm{O}_{2}$ molecules (quenching reactions) and then $\mathrm{H}_{2} \mathrm{O}$ molecules in the MBL, producing $\mathrm{OH}$ radicals $\left(\mathrm{O}\left({ }^{1} \mathrm{D}\right)+\right.$
$\mathrm{H}_{2} \mathrm{O} \rightarrow 2 \mathrm{OH}$ ). Therefore, the former could be primarily responsible for photochemical $\mathrm{HCHO}$ production within the MBL.

Figures 3 and 4 show the changes in the ship-plume $\mathrm{HCHO}$ mixing ratios and the source budget of $\mathrm{HCHO}$ generation (photochemical production + direct emission) inside the ITCT 2K2 ship-plume, respectively. Four cases were considered in Figs. 3 and 4: (CASE I) $\mathrm{CH}_{4}+\mathrm{OH}$ reaction $\mathrm{ON}$ inside the ship-plume; (CASE II) $\mathrm{CH}_{4}+\mathrm{OH}$ reaction $\mathrm{ON}+\mathrm{NMVOC}$ emission without primary $\mathrm{HCHO}$ emission; (CASE III) $\mathrm{CH}_{4}+\mathrm{OH}$ reaction $\mathrm{ON}+\mathrm{NMVOC}$ emission with primary HCHO emission; and (Background): only with the $\mathrm{HCHO}$ background mixing ratios. Figure $3 \mathrm{a}$ and $\mathrm{b}$, the first and the second rows in Fig. 3, show the changes in the crosssection averaged ship-plume HCHO mixing ratios with respect to the ship-plume travel time (Fig. 3a, first row) and the differences between the averaged ship-plume HCHO mixing ratios and model-simulated background $\mathrm{HCHO}$ mixing ratios 
Table 3. Some reactions related to HCHO photochemistry in the MBL.

\begin{tabular}{|c|c|c|}
\hline Reaction number & Reaction & Rate constant \\
\hline (R1) & $\mathrm{CH}_{4}+\mathrm{OH}+\mathrm{O}_{2} \rightarrow \mathrm{CH}_{3} \mathrm{O}_{2}+\mathrm{H}_{2} \mathrm{O}$ & $k_{1}$ \\
\hline (R2) & $\mathrm{CH}_{4}+\mathrm{O}\left({ }^{1} \mathrm{D}\right)+\mathrm{O}_{2} \rightarrow \mathrm{CH}_{3} \mathrm{O}_{2}+\mathrm{OH}$ & $k_{2}$ \\
\hline (R3) & $\mathrm{CH}_{4}+\mathrm{O}\left({ }^{1} \mathrm{D}\right) \rightarrow \mathrm{HCHO}+\mathrm{H}_{2}$ & $k_{3}$ \\
\hline (R4) & $\mathrm{CH}_{3} \mathrm{O}_{2}+\mathrm{NO} \rightarrow \mathrm{CH}_{3} \mathrm{O}+\mathrm{NO}_{2}$ & $k_{4}$ \\
\hline (R5) & $\mathrm{CH}_{3} \mathrm{O}+\mathrm{O}_{2} \rightarrow \mathrm{HCHO}+\mathrm{HO}_{2}$ & $k_{5}$ \\
\hline (R6) & $\mathrm{CH}_{3} \mathrm{O}_{2}+\mathrm{CH}_{3} \mathrm{O}_{2} \rightarrow \mathrm{CH}_{3} \mathrm{OH}+\mathrm{HCHO}+\mathrm{O}_{2}$ & $k_{6}$ \\
\hline (R7) & $\mathrm{CH}_{3} \mathrm{OOH}+\mathrm{OH} \rightarrow \mathrm{HCHO}+\mathrm{OH}+\mathrm{H}_{2} \mathrm{O}$ & $k_{7}$ \\
\hline (R8) & $\mathrm{CH}_{2} \mathrm{OH}+\mathrm{O}_{2} \rightarrow \mathrm{HCHO}+\mathrm{HO}_{2}$ & $k_{8}$ \\
\hline (R9) & $\mathrm{HCHO}+h v \rightarrow \mathrm{CHO}+\mathrm{H}$ & $J_{1}$ \\
\hline (R10) & $\mathrm{HCHO}+h v \rightarrow \mathrm{CO}+\mathrm{H}_{2}$ & $J_{2}$ \\
\hline (R11) & $\mathrm{HCHO}+\mathrm{OH} \rightarrow \mathrm{CHO}+\mathrm{H}_{2} \mathrm{O}$ & $k_{9}$ \\
\hline (R12) & $\mathrm{HCHO}+\mathrm{NO}_{3} \rightarrow \mathrm{CHO}+\mathrm{HNO}_{3}$ & $k_{10}$ \\
\hline (R13) & $\mathrm{HCHO}+\mathrm{O}\left({ }^{3} \mathrm{P}\right) \rightarrow \mathrm{CHO}+\mathrm{OH}$ & $k_{11}$ \\
\hline
\end{tabular}
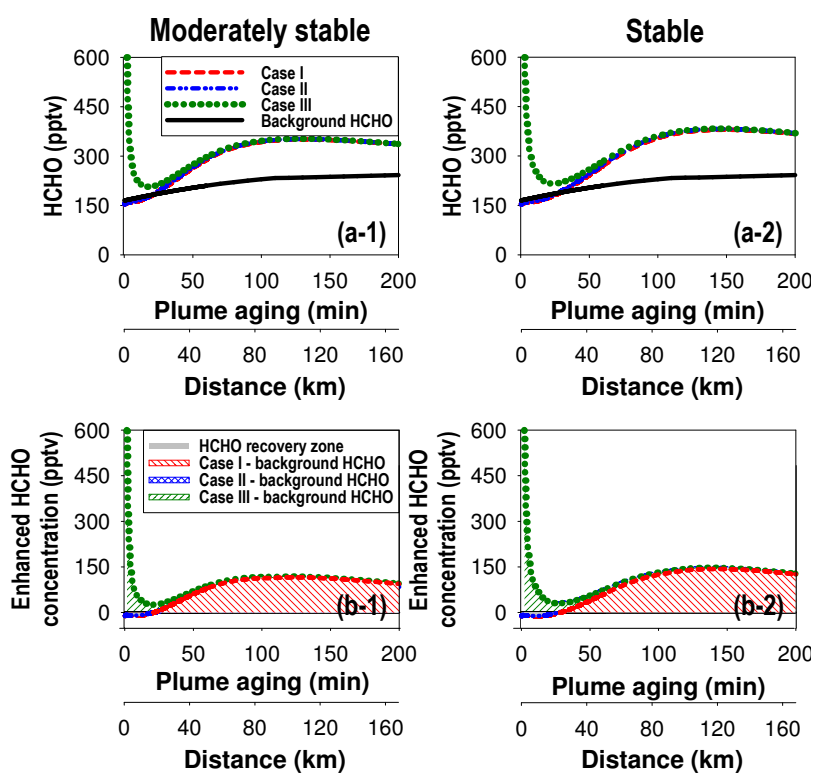

Fig. 3. Cross-section averaged $\mathrm{HCHO}$ mixing ratios from three case simulations (CASEs I, II, and III) and Background HCHO mixing ratios: (a) changes in the cross-section averaged ship-plume $\mathrm{HCHO}$ mixing ratios; (b) differences between the cross-section averaged ship-plume HCHO mixing ratios and the model-simulated background HCHO mixing ratios. The first and second columns show the results from the model-simulations under the moderately stable (E) and stable (F) MBL conditions, respectively.

(Fig. 3b, second row), respectively. As shown in Fig. 3, neither the direct emission of HCHO from the ship (e.g., see the differences between red-dashed lines and green-dotted lines in the first row of Fig. 3) nor atmospheric oxidation of NMVOCs emitted from the ship (e.g., see the differences between red-dashed lines and blue-dotted lines in the first row of Fig. 3) is the major factor that can completely explain the elevated levels of $\mathrm{HCHO}$ within the ship plume.
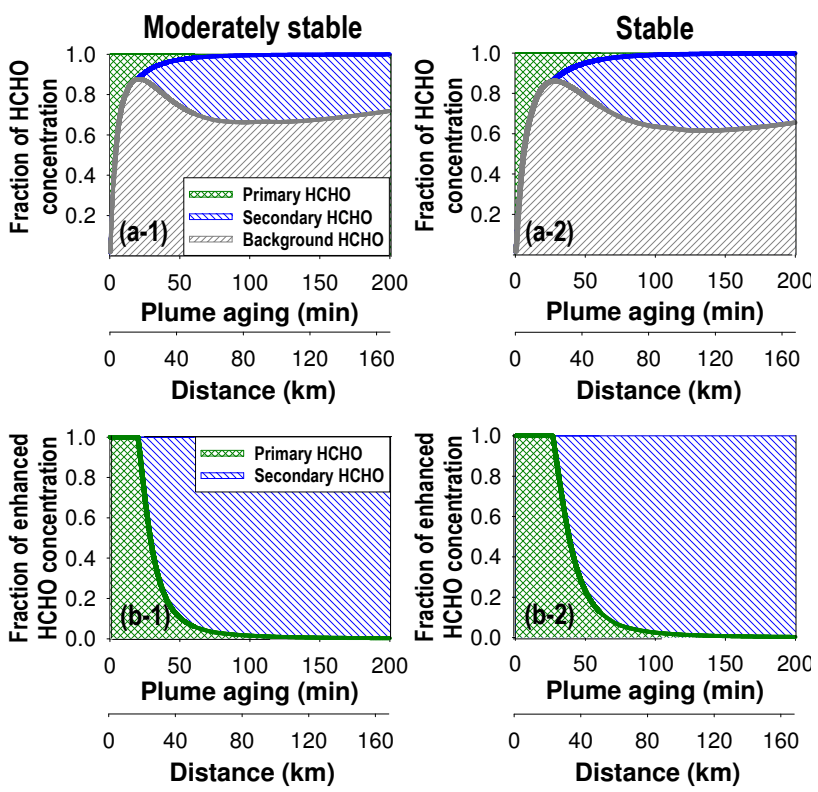

Fig. 4. $\mathrm{HCHO}$ budget by sources for the ITCT $2 \mathrm{~K} 2$ ship-plume case: (a) source fraction of the ship-plume HCHO mixing ratios and (b) source fractions of the enhanced ship-plume HCHO mixing ratios. The first and second columns show the results from the model-simulations under the moderately stable (E) and stable (F) MBL conditions, respectively.

Instead, the enhanced rate of the atmospheric oxidation of $\mathrm{CH}_{4}$ (e.g., check the differences between red-dashed lines and black-solid lines in the first row of Fig. 3) is the most likely cause for the enhanced HCHO levels. The crosssection averaged ship-plume HCHO mixing ratios and the differences in Fig. 3 are a function of the stability class of the MBL. In other words, both ship-plume HCHO mixing ratios and their differences tend to increase slightly as the MBL changes from moderately stable (E) to stable (F) conditions. 
The increases are due mainly to the atmospheric $\mathrm{CH}_{4}$ oxidation (see CASE I in Fig. 3). The increased $\mathrm{CH}_{4}$ oxidation is certainly due to the increased $\mathrm{OH}$ radical concentrations inside the ITCT $2 \mathrm{~K} 2$ ship plume (this will be discussed further in Fig. 6).

In addition, as shown in Fig. 3, there was almost no difference between CASEs I and II. Although the "total NMVOC" emission rates are up to $5 \%$ of the ship $\mathrm{NO}_{\mathrm{x}}$ emission rates in the simulations, the emission rates of the "individual" NMVOC species in the model simulations (refer to Table 1) are small because they are chemically-lumped (or chemically-split) into eight individual NMVOC species in the simulations. In reality, they would be even more chemically-split because NMVOCs are composed of many different individual species. The relatively low emissions of the individual NMVOCs (due to chemical species split) are then diluted rapidly and concurrently, resulting in minimal impacts of NMVOC emissions from the ship. More importantly, the dilution of NMVOCs actually occurs in the early ship-plume stage, where oxidation is not yet very active due to the depletion of $\mathrm{OH}$ radicals (this will be discussed further below). Due to these two reasons, the simulations with and without NMVOC emissions (CASEs I and II) produced similar (almost identical) results. In this sense, ship-emitted NMVOCs are not responsible for the HCHO enhancements "inside the ship plumes". However, the diluted NMVOCs would contribute to $\mathrm{HCHO}$ production "in the background air". This will be discussed further in the later part of this section. Wagner et al. (2002) reported that approximately $\sim 22.7 \%$ of $\mathrm{HCHO}$ could be produced from the background NMVOCs over the South Indian Ocean (SIO).

Here, there are two important issues, particularly near the ship stack (approximately, within the ship-plume travel time of $\sim 30 \mathrm{~min}$ ): (1) the levels of the cross-section averaged ship-plume HCHO are slightly below the background HCHO levels near the ship stack (compare CASEs I and II with "Background HCHO" in Fig. 3a-1 and a-2 and also check the grey parts below zero lines in Fig. 3b-1 and b-2) and (2) the primary $\mathrm{HCHO}$ emitted from the ship could make a significant contribution to the levels of the averaged ship-plume HCHO near the ship stack (CASE III in Fig. 3). The former is basically due to ozone titration near the ship stack. The ozone titration near the ship stack is well known and has been discussed in many papers (e.g., Song et al., 2003a; von Glasow et al., 2003; Kim et al., 2009). Ozone titration then leads to $\mathrm{OH}$ depletion near the ship stack and causes an imbalance between HCHO production and destruction inside the ship plume (i.e., $\mathrm{HCHO}$ production rate $<\mathrm{HCHO}$ destruction rate). Therefore, the levels of $\mathrm{HCHO}$ near the ship stack fall slightly below the background HCHO levels inside the ship plume (hereafter, called "HCHO depletion"). However, the HCHO depletion near the ship stack is not as serious as the $\mathrm{OH}$ depletion, since the chemical lifetimes of $\mathrm{HCHO}$ due to its photo-dissociation reactions are still 4-5 hrs (note the magnitudes of two $J(\mathrm{HCHO})$ values in Table 2 ).
When the primary $\mathrm{HCHO}$ emission from the ship is considered (CASE III, the most realistic case), the primary HCHO can compensate for the depletion of $\mathrm{HCHO}$ and enhances the levels of HCHO near the ship stack. These dynamic changes in the HCHO budget are certainly due to the "nonlinear" characteristics of the ship-plume photochemistry.

In order to analyse the $\mathrm{HCHO}$ budget in more detail for CASE III (the most realistic case), the source fractions of the ship-plume HCHO mixing ratios and enhanced ship-plume HCHO mixing ratios are depicted in Fig. $4 \mathrm{a}$ and b, respectively. As shown in Fig. 4a and b, until a ship-plume travel time of $\sim 20 \mathrm{~min}$, primary $\mathrm{HCHO}$ emission is the main source of the HCHO enhancement inside the ship plume. The primary $\mathrm{HCHO}$ contributes continuously to ship-plume $\mathrm{HCHO}$ generation until $\sim 50 \mathrm{~min}$ after the ship puff is released. However, $\mathrm{CH}_{4}$ oxidation becomes the major contributor after a ship-plume travel time of $\sim 40 \mathrm{~min}$. In particular, after a ship-plume travel time of 70 min, almost all the $\mathrm{HCHO}$ enhancement is due to atmospheric $\mathrm{CH}_{4}$ oxidation.

Figure 5 shows the cross-sectional profiles of the HCHO mixing ratios in the ITCT $2 \mathrm{~K} 2$ ship-plume at six transects (including two imaginary transects $\mathrm{A}^{-}$and $\mathrm{A}^{\circ}$ ). Two issues should be noted in Fig. 5: (1) the contribution of primary $\mathrm{HCHO}$ emissions to the cross-sectional HCHO profiles of the ITCT $2 \mathrm{~K} 2$ ship plume depends on the stability condition of the MBL; the contribution of primary $\mathrm{HCHO}$ to the total $\mathrm{HCHO}$ profiles last longer, as the MBL becomes more stable and (2) the cross-sectional profiles of the $\mathrm{HCHO}$ mixing ratios initially show a minimum in the plume core; the duration of this effect depends again on the stability of the MBL. These "non-Gaussian" HCHO profiles across the ship plume are important evidence of the nonlinear ship-plume photochemistry (Kim et al., 2009). The non-Gaussian shapes of the cross-sectional HCHO profiles also last longer as the MBL becomes more stable (because ship plumes are spread more narrowly when the MBL becomes more stable, as shown in Fig. 5). However, as ship-plume ages photochemically and dynamically, the cross-sectional HCHO profiles become Gaussian and the contribution of primary HCHO to the profiles of HCHO mixing ratios becomes smaller. In addition, the $\mathrm{HCHO}$ levels also increase, as the MBL becomes more stable. For example, the peak HCHO mixing ratios are elevated above the background HCHO levels by $\sim 160 \mathrm{pptv}$ (at transect $\mathrm{H}$ ) under stable MBL conditions, whereas they are elevated only by $\sim 120 \mathrm{pptv}$ (at transect $\mathrm{H}$ ) under moderately stable MBL conditions. These increases in the HCHO levels were used in Sect. 3.2 as an indicator of the degree of activity of the HCHO-related photochemistry inside the ship plume.

Figure 6 represents the $\mathrm{OH}$ radical concentrations, instantaneous chemical lifetime of $\mathrm{CH}_{4}\left(\tau_{\mathrm{CH}_{4}}\right)$, and the net instantaneous $\mathrm{HCHO}$ production rate $\left(P_{\mathrm{HCHO}}\right)$ at six ship-plume transects under moderately stable and stable MBL conditions. The rates of $\mathrm{CH}_{4}$ and $\mathrm{HCHO}$ destructions $\left(D_{\mathrm{CH}_{4}}\right.$ and $D_{\mathrm{HCHO}}$, respectively) in Fig. 6 were calculated as follows: 

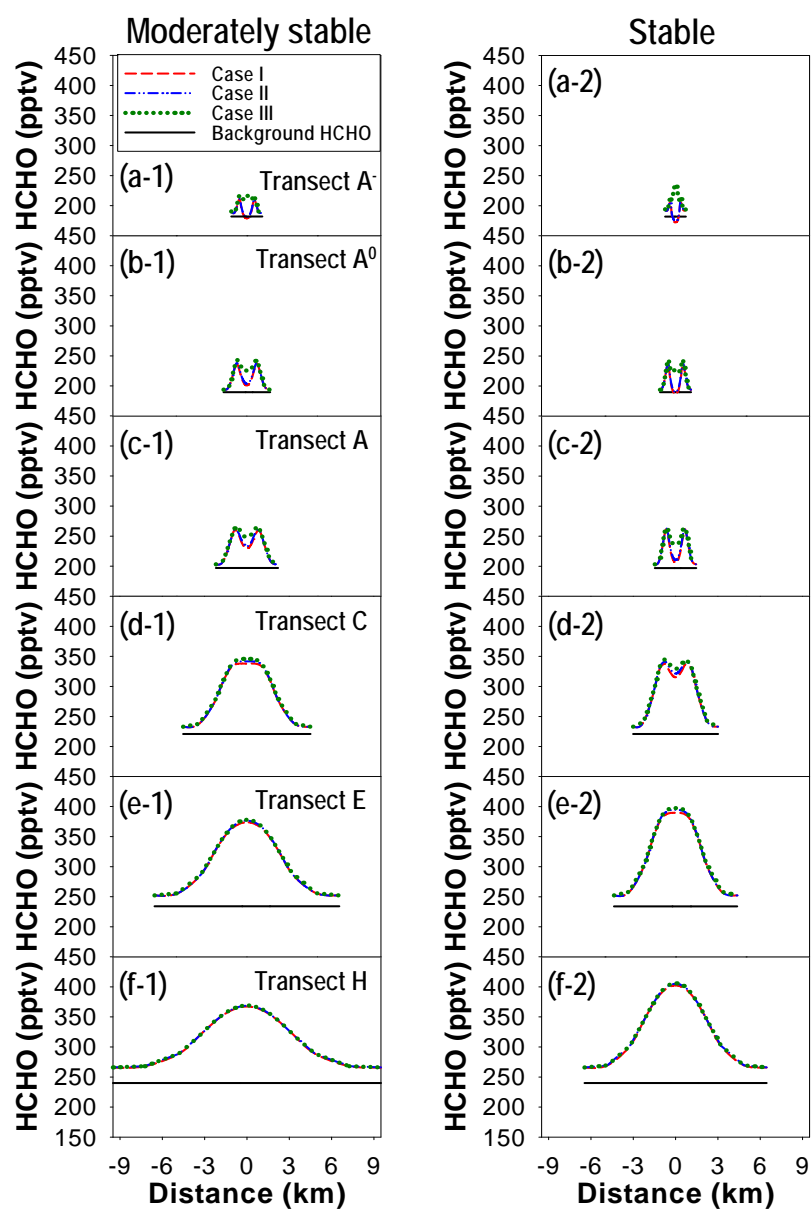

Fig. 5. Profiles of $\mathrm{HCHO}$ mixing ratios inside the ITCT $2 \mathrm{~K} 2$ shipplume at six transects: (a) transect $\mathrm{A}^{-}$; (b) transect $\mathrm{A}^{\circ}$; (c) transect $\mathrm{A}$; (d) transect $\mathrm{C}$; (e) transect $\mathrm{E}$; and (f) transect $\mathrm{H}$. The first and second columns show the results from the model-simulations under moderately stable (E) and stable (F) MBL conditions, respectively.

$$
D_{\mathrm{CH}_{4}}=\left\{k_{1}[\mathrm{OH}]+k_{2}\left[\mathrm{O}^{1} \mathrm{D}\right]+k_{3}\left[\mathrm{O}^{1} \mathrm{D}\right]\right\}\left[\mathrm{CH}_{4}\right]
$$

$$
D_{\mathrm{HCHO}}=\left\{J_{1}+J_{2}+k_{9}[\mathrm{OH}]+k_{10}\left[\mathrm{NO}_{3}\right]+k_{11}\left[\mathrm{O}^{3} \mathrm{P}\right]\right\}[\mathrm{HCHO}]
$$

The rate of $\mathrm{HCHO}$ formation from both $\mathrm{CH}_{4}$ and NMVOCs oxidation reactions $\left(F_{\mathrm{HCHO}}\right)$ was calculated from Eq. (3):

$$
\begin{aligned}
& F_{\mathrm{HCHO}} \approx F_{\mathrm{HCHO}}^{\mathrm{CH}_{4}} \\
& +\sum_{i}^{3} \sum_{j}^{n} \Phi_{j} k_{X_{i}+\mathrm{NMVOCs}_{j}}\left[X_{i}\right]\left[\mathrm{NMVOCs}_{j}\right] \\
& F_{\mathrm{HCHO}}^{\mathrm{CH}_{4}}=k_{5}\left[\mathrm{CH}_{3} \mathrm{O}\right]\left[\mathrm{O}_{2}\right]+k_{6}\left[\mathrm{CH}_{3} \mathrm{O}_{2}\right]^{2} \\
& \quad+k_{7}\left[\mathrm{CH}_{3} \mathrm{OOH}\right][\mathrm{OH}]+k_{8}\left[\mathrm{CH}_{2} \mathrm{OH}\right]\left[\mathrm{O}_{2}\right]
\end{aligned}
$$

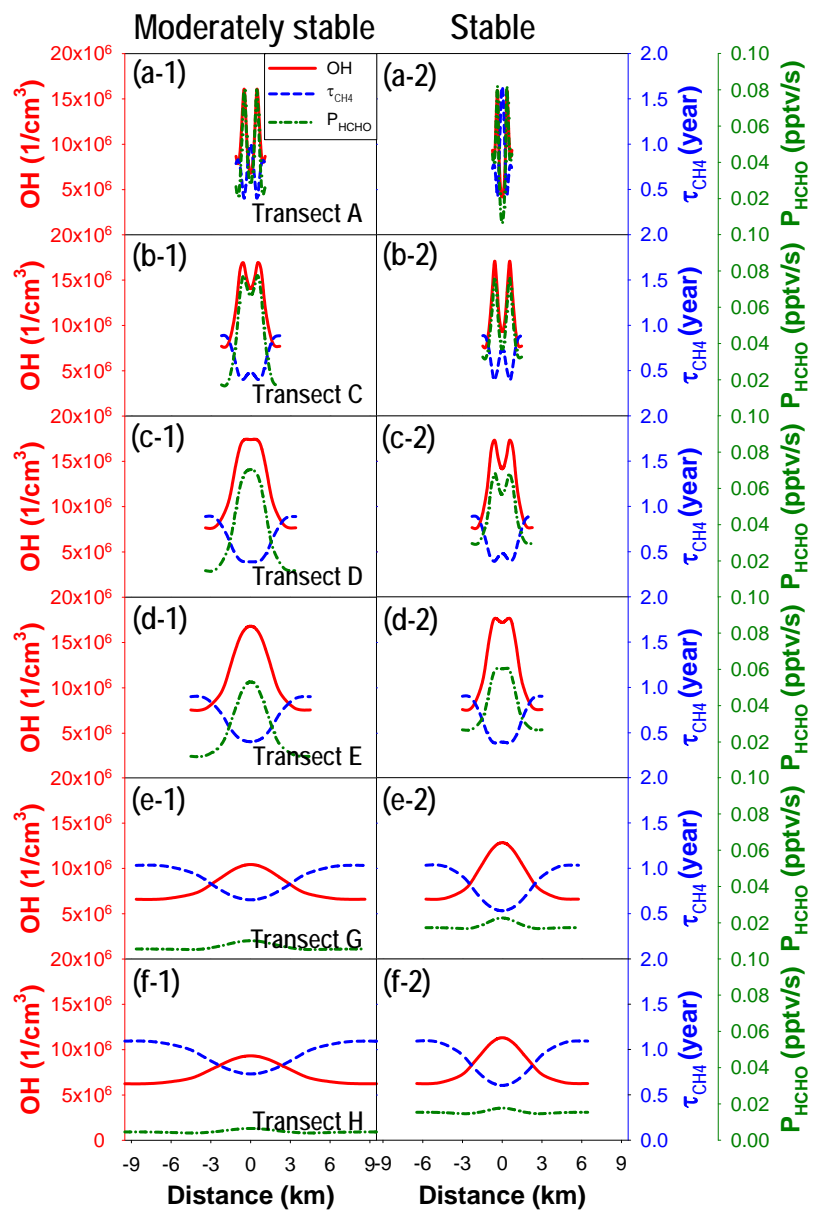

Fig. 6. Profiles of $\mathrm{OH}$ radical concentrations (red-solid lines), instantaneous chemical lifetime of $\mathrm{CH}_{4}\left(\tau_{\mathrm{CH}_{4}}\right.$, blue-dashed lines), and net instantaneous $\mathrm{HCHO}$ production rate $\left(P_{\mathrm{HCHO}}\right.$, green-dotted lines) at six ship-plume transects under moderately stable and stable MBL conditions.

$$
\begin{aligned}
F_{\mathrm{HCHO}} & \approx F_{\mathrm{HCHO}}^{\mathrm{CH}_{4}}, \text { when } F_{\mathrm{HCHO}}^{\mathrm{CH}_{4}} \\
\gg & \sum_{i}^{3} \sum_{j}^{n} \Phi_{j} k_{X_{i}+\text { NMVOCs }_{j}}\left[X_{i}\right]\left[\text { NMVOCs }_{j}\right] \\
\tau_{\mathrm{CH}_{4}} & =\frac{\left[\mathrm{CH}_{4}\right]}{D_{\mathrm{CH}_{4}}}
\end{aligned}
$$

where $F_{\mathrm{HCHO}}^{\mathrm{CH}_{4}}$ denote the rate of $\mathrm{HCHO}$ formation only from $\mathrm{CH}_{4}$ oxidation and $k_{i}$ is the thermal reaction rate constant $\left(\mathrm{cm}^{3}\right.$ molecules ${ }^{-1} \mathrm{~s}^{-1}$ ) (see Table 3). $k_{X_{i}+\text { NMVOCs, } j}$ is the reaction rate constant $\left(\mathrm{cm}^{3}\right.$ molecules $\left.{ }^{-1} \mathrm{~s}^{-1}\right)$ for HCHO production from the oxidation of NMVOC species $j$ by atmospheric oxidants, $X_{i}$ (here, $X_{i}=\mathrm{OH}, \mathrm{O}_{3}$, and $\mathrm{NO}_{3}$ ) and $\Phi_{j}$ is the $\mathrm{HCHO}$ yield from the oxidation of NMVOC species $j$. In the actual calculations, a full set of the $\mathrm{HCHO}$ formation reactions was used to estimate $F_{\mathrm{HCHO}}$. Here, a rather conceptual expression, using $k_{X_{i}+\text { NMVOCs, } j}$ and $\Phi_{j}$, is shown on the right-hand side of Eq. (3) (for a description of the full set of 
the HCHO formation reactions, refer to Appendix). Obviously, $\Phi_{j}$ has a different value under different atmospheric chemical conditions.

Another possible oxidation reaction of $\mathrm{CH}_{4}$ would be $\mathrm{CH}_{4}+\mathrm{Cl}$ in the MBL (Sander and Crutzen, 1996; Vogt et al., 1996; Wagner et al., 2002; von Glasow et al., 2003). However, these reactions were not considered in this study because there was no clear evidence of halogen-mediated photochemistry found in this specific ship-plume case (Parrish et al., 2004; Chen et al., 2005; Kim et al., 2009).

As discussed above, $\mathrm{CH}_{4}$ is destroyed/oxidized, producing $\mathrm{HCHO}$ and $\mathrm{CH}_{3} \mathrm{O}_{2}$ radicals. $\mathrm{CH}_{3} \mathrm{O}_{2}$ radicals are subsequently converted to $\mathrm{HCHO}$ via Reactions (R4)-(R6), as shown in Table 3 (Finlayson-Pitts and Pitts, 2000; Wagner et al., 2002). $\mathrm{CH}_{3} \mathrm{OOH}$ and $\mathrm{CH}_{2} \mathrm{OH}$ can also produce $\mathrm{HCHO}$ via (R7) and (R8) in Table 3. Although both $\mathrm{CH}_{3} \mathrm{OOH}$ and $\mathrm{CH}_{3} \mathrm{OH}$ (precursor of $\mathrm{CH}_{2} \mathrm{OH}, \mathrm{CH}_{3} \mathrm{OH}+\mathrm{OH} \rightarrow \mathrm{CH}_{2} \mathrm{OH}$ ) produce $\mathrm{HCHO}$ via (R7) and (R8), the production rates are slow, because both species are "reservoir" species. Moreover, the ship-plume situations inherently create high $\mathrm{NO}_{\mathrm{x}}$ conditions $\left(\mathrm{HO}_{\mathrm{x}}\right.$-limited situations), which limits the formation of the both reservoir species. Under such high $\mathrm{NO}_{\mathrm{x}}$ conditions, at a pseudo steady-state the rates of $\mathrm{CH}_{4}$ destruction $\left(D_{\mathrm{CH}_{4}}\right)$ are approximately equal to the rates of $\mathrm{HCHO}$ production $\left(F_{\mathrm{HCHO}}\right)$, i.e.:

$D_{\mathrm{CH}_{4}} \cong F_{\mathrm{HCHO}} \cong F_{\mathrm{HCHO}}^{\mathrm{CH}_{4}}$

when $F_{\mathrm{HCHO}}^{\mathrm{CH}_{4}} \gg \sum_{i}^{3} \sum_{j}^{n} \Phi_{j} k_{X_{i}+\mathrm{NMVOCs}_{j}}\left[X_{i}\right]\left[\mathrm{NMVOCs}_{j}\right]$

In other words, the $\mathrm{CH}_{4}$ oxidation is the dominant and rate-determining (very slow) step of the entire HCHO production processes within the ship plumes. As discussed previously, HCHO production from the NMVOC oxidation "inside the ship plume" is minor compared to that from $\mathrm{CH}_{4}$ oxidation $\left(D_{\mathrm{CH}_{4}}\right)$, due to the rapid and concurrent individual species dilutions and the $\mathrm{OH}$ radical deletion. This was confirmed in Fig. 7.

In the current framework of the analysis, two points should be considered: (1) the changes in the quantities inside and outside the ship-plume; and (2) the imbalance between $D_{\mathrm{CH}_{4}}$ $\left(\approx F_{\mathrm{HCHO}}\right)$ and $D_{\mathrm{HCHO}}$ inside the ship plume. The former was examined to compare the characteristics of $\mathrm{CH}_{4}$ destruction and $\mathrm{HCHO}$ formation inside and outside the ship-plume. In the latter, the difference between $F_{\mathrm{HCHO}}$ and $D_{\mathrm{HCHO}}$ can be regarded as the net instantaneous $\mathrm{HCHO}$ production rate $\left(P_{\mathrm{HCHO}}\right)$, i.e.:

$$
P_{\mathrm{HCHO}} \approx F_{\mathrm{HCHO}}-D_{\mathrm{HCHO}} \approx D_{\mathrm{CH}_{4}}-D_{\mathrm{HCHO}}
$$

Figure 7 compares the two net cross-section averaged instantaneous $\mathrm{HCHO}$ production rates $\left(\overline{P_{\mathrm{HCHO}}}\right)$ for the two MBL stability conditions. The black solid and red dashed lines represent the two $\overline{P_{\mathrm{HCHO}}}$ expressions defined by $D_{\mathrm{CH}_{4}}-$ $D_{\mathrm{HCHO}}$ and $F_{\mathrm{HCHO}}-D_{\mathrm{HCHO}}$ in Eq. (6), respectively. The
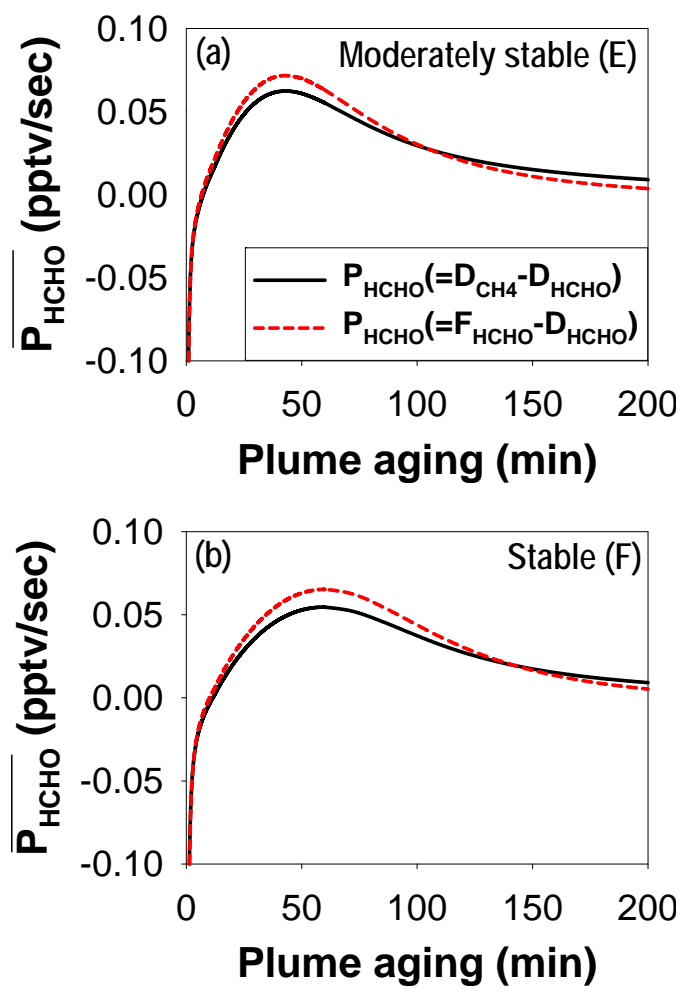

Fig. 7. Comparison between two $\overline{P_{\mathrm{HCHO}}}$ : (1) $D_{\mathrm{CH}_{4}}-D_{\mathrm{HCHO}}$ (black-solid lines) and (2) $F_{\mathrm{HCHO}}-D_{\mathrm{HCHO}}$ (red-dashed lines). Panels (a) and (b) show the results from the model-simulations under the moderately stable (E) and stable (F) MBL conditions, respectively.

two lines show the differences around the peak $\overline{P_{\mathrm{HCHO}}}$ values. However, the differences are not large (up to $\sim 17 \%$ at the peak $\overline{P_{\mathrm{HCHO}}}$ values under the stable MBL condition, see Fig. 7b). Here, the differences between $D_{\mathrm{CH}_{4}}-$ $D_{\mathrm{HCHO}}$ and $F_{\mathrm{HCHO}}-D_{\mathrm{HCHO}}$ around the plume travel times of 20-70 min could indicate the influences of the term, $\sum_{i}^{3} \sum_{j}^{n} \Phi_{j} k_{X_{i}+\mathrm{NMVOCs}_{j}}\left[X_{i}\right]\left[\mathrm{NMVOCs}_{j}\right]$, in Eq. (3). On the other hand, the negative $\overline{P_{\mathrm{HCHO}}}$ values until $\sim 20 \mathrm{~min}$ after the ship plume is released indicate net HCHO destruction, mainly via active Reactions (R9)-(R11) (see Table 3), which are due to $\mathrm{OH}$ depletion during the early ship-plume photochemical stage.

Figure 8 presents the budget analysis of the HCHO formation $\left(F_{\mathrm{HCHO}}\right)$ and the $\mathrm{HCHO}$ destruction $\left(D_{\mathrm{HCHO}}\right)$ for the ITCT 2 K2 ship plume under moderately stable MBL condition. As shown in Fig. 8a, approximately $88 \%$ of HCHO inside the ITCT $2 \mathrm{~K} 2$ ship plume was produced via the $\mathrm{CH}_{4}$ oxidation (through Reactions (R1) to (R5) in Table 3). The other $\sim 12 \%$ was contributed from NMVOC oxidations (regarding the details, refer to the caption of Fig. 8). However, this budget analysis should be interpreted with care. The $12 \%$ contribution from the NMVOC oxidations includes the effects 

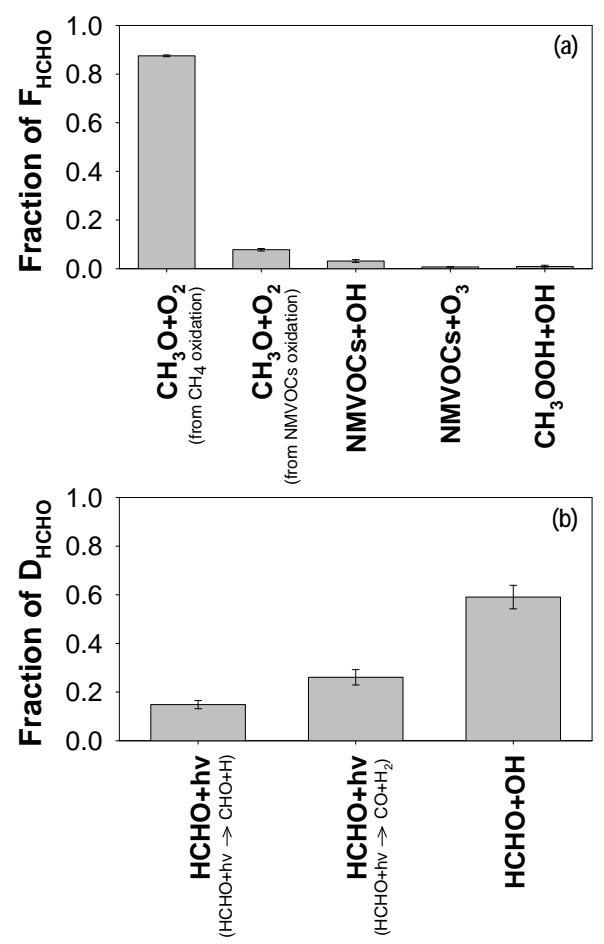

Fig. 8. Budget analysis of the $\mathrm{HCHO}$ formation $\left(F_{\mathrm{HCHO}}\right)$ and $\mathrm{HCHO}$ destruction $\left(D_{\mathrm{HCHO}}\right)$ : (a) contribution of five major $\mathrm{HCHO}$ formation reactions to $F_{\mathrm{HCHO}}$ in the ITCT $2 \mathrm{~K} 2$ ship plume under moderately stable MBL condition. Here, the contributions from NMVOC oxidations (the second, the third and the fourth bars) were estimated from: (i) the calculation of $\mathrm{CH}_{3} \mathrm{O}$ radical production rates from the NMVOC oxidations, (ii) summed rates of NMVOCs (alkane species)+OH reactions, and (iii) summed rates of NMVOCs (mainly, alkene species, including isoprene) $+\mathrm{O}_{3}$ reactions from the modified Lurmann chemical mechanism and (b) contribution of three major $\mathrm{HCHO}$ loss reactions to $D_{\mathrm{HCHO}}$ in the ITCT $2 \mathrm{~K} 2 \mathrm{ship}$ plume under moderately stable MBL condition.

of the HCHO productions in the background air. Again, as shown in Figs. 3 and 4, the consideration of the NMVOC emission from ship cannot enhance the levels of HCHO inside the ITCT 2K2 ship-plume. On the other hand, approximately $59 \%$ of HCHO inside the ITCT $2 \mathrm{~K} 2$ ship plume was destructed via reaction with $\mathrm{OH}$ (Reaction (R11) in Table 3), as shown in Fig. 8b. This percentage of 59\% is larger than that in the other typical MBL situations. This is again due to the enhanced levels of $\mathrm{OH}$ inside the ship plume. About $15 \%$ and $26 \%$ of HCHO inside the ITCT 2K2 ship plume were destructed via two photo-dissociation reactions, (R9) and (R10) in Table 3, respectively.

Figure 6 presents the cross-sectional variations of the quantities defined in Eqs. (1)-(6) for moderately stable and stable MBL conditions. The quantities vary depending on the stability classes of the MBL. First of all, the peak $\mathrm{OH}$ radical concentrations increase, even up to $\sim 1.7 \times 10^{7}$ molecules $\mathrm{cm}^{-3}$ for both the MBL conditions. These lev- els of $\mathrm{OH}$ radicals are $\sim 2.8$ times higher than the background levels of $\mathrm{OH}\left(\sim 6.1 \times 10^{6}\right.$ molecules $\mathrm{cm}^{-3}$, refer to Chen et al., 2005), indicating $\sim 2.8$ times faster atmospheric $\mathrm{CH}_{4}$ oxidation inside the ship plume than that in the background (out-plume) MBL. This was confirmed in terms of $\tau_{\mathrm{CH}_{4}} \cdot \tau_{\mathrm{CH}_{4}}$ is approximately $\sim 1.1 \mathrm{yr}$ in the background, but as low as $\sim 0.45 \mathrm{yr}$ inside the ship plume. $\tau_{\mathrm{CH}_{4}}$ at the peak of the ship plume was approximately $\sim 41 \%$ lower than $\tau_{\mathrm{CH}_{4}}$ in the background under the moderately stable MBL conditions. Under stable MBL conditions, $\tau_{\mathrm{CH}_{4}}$ was shortened even further. Here, it should be emphasized once again that $\tau_{\mathrm{CH}_{4}}$ is a function of the $\mathrm{OH}$ radical concentration. Our ship-plume model simulations can successfully regenerate, e.g., $\sim 8 \mathrm{yr}$ of $\mathrm{CH}_{4}$ lifetime (approximately, globallyaveraged value at daytime), when the $\mathrm{OH}$ radical concentration is $1.02 \times 10^{6}$ molecules $\mathrm{cm}^{-3}$, as reported by the Oslo global CTM simulation by Karlsdóttir and Isaksen (2000).

As mentioned above, the imbalance between $D_{\mathrm{CH}_{4}}(\approx$ $\left.F_{\mathrm{HCHO}}\right)$ and $D_{\mathrm{HCHO}}$ inside the ship plume was also examined. Basically, it is the imbalance that enhances the ship-plume HCHO levels (or depletion of the HCHO mixing ratios close to the ship stack). As shown in Fig. 6, $P_{\mathrm{HCHO}}$ inside the ship plume has values above the background $P_{\mathrm{HCHO}}$, indicating excessive $\mathrm{HCHO}$ formation inside the ship plume. The background $P_{\mathrm{HCHO}}$ ranges from $\sim 0.02$ to $\sim 0.03 \mathrm{pptv} \mathrm{s}^{-1}$, whereas the ship-plume $P_{\mathrm{HCHO}}$ increases up to $\sim 0.08 \mathrm{pptv} \mathrm{s}^{-1}$. Such an imbalance leads to large increases in the HCHO levels inside the ship plume, as shown in Fig. 5. However, some depletion at the shipplume centre is also found near the ship locations between transects $\mathrm{A}^{-}$and $\mathrm{B}$. Again, this is due mainly to the retarded $F_{\mathrm{HCHO}}$ caused by $\mathrm{OH}$ depletion. Figure 9 shows the timedependent changes in the cross-section averaged $\mathrm{OH}$ radical concentrations $([\overline{\mathrm{OH}}])$, net instantaneous cross-section averaged chemical lifetime of $\mathrm{CH}_{4}\left(\overline{\mathrm{\tau}_{4}}\right)$, and net instantaneous cross-section averaged $\mathrm{HCHO}$ production rate $\left(\overline{P_{\mathrm{HCHO}}}\right)$ under moderately stable and stable MBL conditions. In Fig. 9, one could also find a very dynamic, nonlinear nature of the ship-plume photochemistry. Near the ship stack, both $[\overline{\mathrm{OH}}]$ and $\overline{P_{\mathrm{HCHO}}}$ are very low, whereas $\overline{\tau_{\mathrm{CH}_{4}}}$ are high. However, as ship plume travels, $[\overline{\mathrm{OH}}]$ recovers and $\overline{P_{\mathrm{HCHO}}}$ increases accordingly. In contrast, $\overline{\tau_{\mathrm{CH}_{4}}}$ decreases. Then, after 50 $80 \mathrm{~min}$, both $[\overline{\mathrm{OH}}]$ and $\overline{P_{\mathrm{HCHO}}}$ decrease again.

\subsection{Constructed case studies}

As mentioned in Sect. 2.3.3, basically twelve scenario simulations were carried out at each latitude, changing the MBL stability conditions from neutral to stable (i.e., stability classes of $\mathrm{D}, \mathrm{E}$ and $\mathrm{F}$ ) and $\mathrm{NO}_{\mathrm{x}}$ emission rates from 3 to $12 \mathrm{~g} \mathrm{~s}^{-1}$ (i.e., 3, 6, 9 and $12 \mathrm{~g} \mathrm{~s}^{-1}$ ). Here, the neutral MBL condition was added to the analysis because it was reported to be the most common stability class within the remote MBL. The numbering for the 12 scenarios was made sequentially from scenarios I-a to III-d (regarding the numbering 

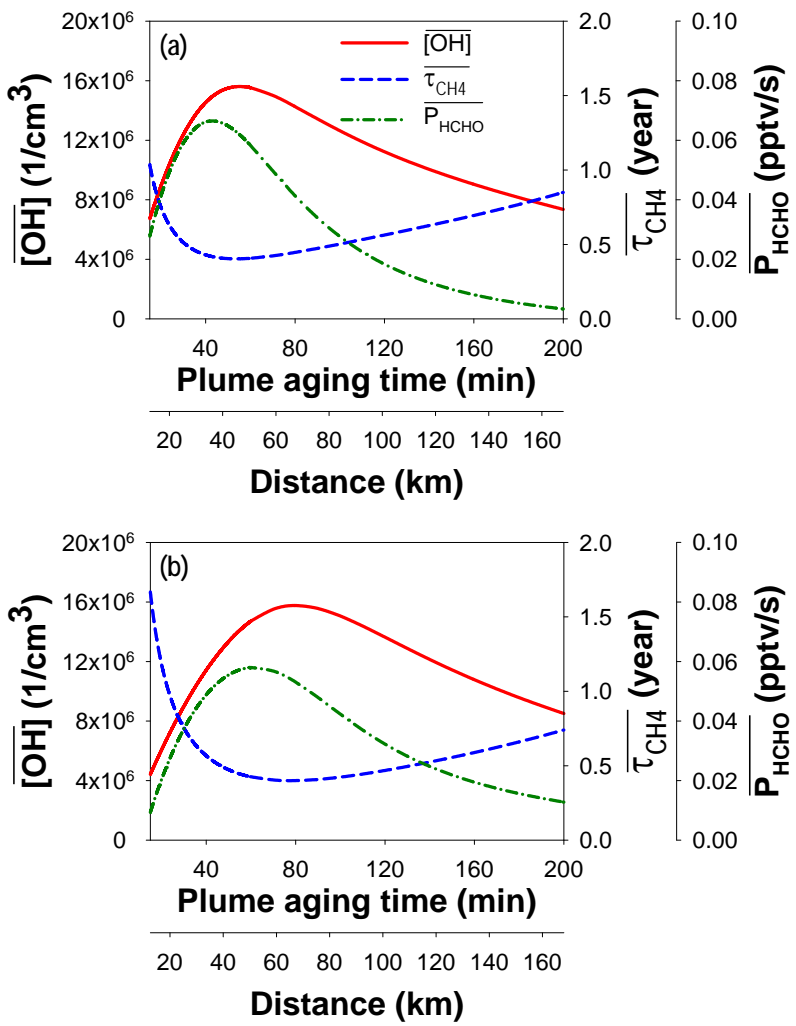

Fig. 9. Changes in the cross-section averaged $\mathrm{OH}$ radical concentrations (red-solid lines), instantaneous chemical lifetime of $\mathrm{CH}_{4}$ ( $\tau_{\mathrm{CH}_{4}}$, blue-dashed lines), and net instantaneous $\mathrm{HCHO}$ production rate $\left(P_{\mathrm{HCHO}}\right.$, green-dotted lines) with respect to ship-plume travel time (or distance) (a) under moderately stable MBL condition and (b) under stable MBL condition.

convention, refer to the footnote of Table 4). The simulations at each latitude were extended further to account for seasonal variations in the HCHO-related photochemistry by carrying out the simulations at four Julian days of 80,173 , 267 and 356, which correspond to the spring equinox, summer solstice, fall equinox and winter solstice in the northern hemisphere, respectively. Therefore, a total of forty eight simulations were carried out at each latitude and the results are summarized in Table 4 . While constructing the scenarios, the changes in the primary NMVOC emission rates were excluded, based on our discussions in Sect. 3.1. The $J\left(\mathrm{O}_{3}\right)$ values for the photolysis reaction of $\mathrm{O}_{3}+h v \rightarrow \mathrm{O}\left({ }^{1} \mathrm{D}\right)+\mathrm{O}_{2}$ are presented in Table 2 to show the latitudinal variations in the intensity of solar radiation because the differences in the magnitudes of $J\left(\mathrm{O}_{3}\right)$ lead to different $\mathrm{OH}$ levels. As shown in Table 2, a more polluted background situation was selected for the sub-tropical conditions than for tropical conditions, with an intention of examining the main factor to affect the degree of activity of the HCHO-related photochemistry in the ship-going MBL. Despite all careful considerations, this study did not account for the possible varying seasonal background composition at each latitudinal location.
To examine the enhancements in the HCHO levels, one variable, the maximum difference of $\mathrm{HCHO}$ mixing ratio $\left(\Delta[\mathrm{HCHO}]_{\max }\right)$ between peak HCHO level ([HCHO $\left.]_{\text {peak }}\right)$ inside the ship plume and background HCHO level ([HCHO $\left.]_{\text {back }}\right)$, was chosen from the scenario simulations, i.e.:

$$
\Delta[\mathrm{HCHO}]_{\max }=[\mathrm{HCHO}]_{\text {peak }}-[\mathrm{HCHO}]_{\text {back }}
$$

Table 4 lists the model-calculated maximum differences for the scenarios. In the scenario simulations, all the first plume puffs were released at 10:30 a.m. LST. Therefore, the peak $\mathrm{OH}$ values appeared around noon, after a period of ozone/OH/HCHO depletions. In addition, this is the approximate local pass time of the ESA/ERS-2 GOME satellite sensor (Marbach et al., 2009). This release time was chosen intentionally considering the satellite studies.

The background HCHO levels in this study were again calculated by UBoM $2 \mathrm{~K} 8$ modelling using the method discussed in Sect. 2.3.3. Table 2 lists the calculated background $\mathrm{HCHO}$ mixing ratios. The background $\mathrm{HCHO}$ mixing ratios are lower than those reported by Wagner et al. (2001). The background $\mathrm{HCHO}$ mixing ratios are affected by the background $\mathrm{NO}_{\mathrm{x}}$ and $\mathrm{NMVOC}$ levels and are most sensitive to the isoprene levels (Wagner et al., 2002). However, such levels are highly variable due to their short atmospheric lifetimes. For example, the calculated background HCHO mixing ratios have a higher value (162.3 pptv) in sub-tropical regions despite the less intense solar intensity compared to tropical regions (147.7 pptv). This is because a more polluted background situation in terms of the $\mathrm{O}_{3}, \mathrm{NO}_{\mathrm{x}}$ and NMVOC mixing ratios was chosen for the sub-tropical conditions, as mentioned previously. The high levels of $\mathrm{O}_{3}, \mathrm{NO}_{\mathrm{x}}$ and NMVOCs in the sub-tropical background air enhance the levels of the "background HCHO".

In addition, the peak $\mathrm{HCHO}$ mixing ratios within the ship plumes can also be estimated by adding the calculated background $\mathrm{HCHO}$ levels to the differences in $\mathrm{HCHO}$ mixing ratios $\left(\Delta[\mathrm{HCHO}]_{\max }\right)$ (refer to Eq. 7). Table 4 shows the differences in $\mathrm{HCHO}$ mixing ratios $\left(\Delta[\mathrm{HCHO}]_{\max }\right)$ estimated from the scenario simulations. The magnitudes of $\Delta[\mathrm{HCHO}]_{\max }$ inside the ship plumes are dominated primarily by the changes in three factors: (1) latitude, (3) MBL stability class, and (3) $\mathrm{NO}_{\mathrm{x}}$ emission rates. $\Delta[\mathrm{HCHO}]_{\max }$ becomes larger as the MBL becomes more stable from $\mathrm{D}$ to $\mathrm{F}$ and as the $\mathrm{NO}_{\mathrm{x}}$ emission rate increases from $3 \mathrm{~g} \mathrm{~s}^{-1}$ to $12 \mathrm{~g} \mathrm{~s}^{-1}$. Therefore, the largest differences are simulated in a stable, tropical MBL with a large $\mathrm{NO}_{\mathrm{x}}$ emission rate. In each latitudinal situation, three $\Delta[\mathrm{HCHO}]_{\max }$ values (minimum, middle, and maximum values) are shown, which were selected from the multiple ship-plume scenario simulations under the spring/fall equinox and winter/summer solstice conditions. As expected, the largest and smallest values of $\Delta[\mathrm{HCHO}]_{\max }$ occur under tropical and mid-latitude conditions, respectively. However, the differences between the minimum and maximum $\Delta[\mathrm{HCHO}]_{\max }$ values would be 
Table 4. Maximum enhanced $\mathrm{HCHO}$ mixing ratios $\left(\Delta[\mathrm{HCHO}]_{\max }\right)$ inside the ship plumes from the scenario simulations (unit: pptv).

\begin{tabular}{lrrr}
\hline Scenario & Tropical & Sub-tropical & Mid-latitude \\
\hline I-a & $131.0(125.6,134.3)$ & $80.2(59.8,87.4)$ & $48.8(19.9,61.6)$ \\
I-b & $178.0(172.7,182.2)$ & $112.5(81.8,120.5)$ & $67.9(21.9,87.0)$ \\
I-c & $202.3(202.2,214.0)$ & $133.5(99.5,142.5)$ & $80.3(22.9,102.7)$ \\
I-d & $231.3(224.5,236.8)$ & $149.7(110.8,159.2)$ & $89.2(23.1,114.2)$ \\
II-a & $262.3(257.6,266.0)$ & $167.5(132.8,173.4)$ & $108.3(28.3,129.5)$ \\
II-b & $334.3(327.2,339.1)$ & $220.9(171.2,230.3)$ & $134.4(25.0,168.3)$ \\
II-c & $372.6(362.9,377.0)$ & $249.4(185.9,262.1)$ & $143.4(24.1,189.2)$ \\
II-d & $395.0(382.3,400.5)$ & $266.7(188.5,282.6)$ & $142.2(27.0,201.0)$ \\
III-a & $319.8(313.3,324.6)$ & $209.7(164.2,219.9)$ & $129.3(25.7,106.0)$ \\
III-b & $384.0(374.0,389.5)$ & $258.7(188.8,272.8)$ & $143.8(24.9,196.0)$ \\
III-c & $409.5(393.6,415.8)$ & $278.5(182.4,299.2)$ & $132.8(30.9,209.2)$ \\
III-d & $417.0(393.7,424.9)$ & $282.8(164.4,312.1)$ & $113.4(38.1,212.9)$ \\
\hline
\end{tabular}

Note 1: I, II and III represent the MBL stability conditions of neutral (D), moderately stable (E) and stable (F), respectively, and a, b, c and d denote the ship-plume cases with the $\mathrm{NO}_{\mathrm{x}}$ emission rates of $3,6,9$ and $12 \mathrm{~g} \mathrm{~s}^{-1}$

Note 2: the values were calculated under spring/fall equinox and winter/summer solstice conditions. Two figures in the parentheses represent the minimum and maximum values of the enhanced HCHO mixing ratios among the values calculated from the multiple scenario simulations.

smaller in tropical regions than in the other two locations due to the minimal difference in sun location between the summer and winter solstice over tropical locations.

As discussed by Marbach et al. (2009), the ship-traffic corridor between Sri Lanka and Sumatra is the only location in the world where the tropospheric HCHO columns can be retrieved from the ESA/ERS-2 GOME sensor through their multi-year high-pass filter algorithm. In addition to several methodological benefits mentioned by Marbach et al. (2009), this is also due to the fact that this ship-traffic corridor is one of the busiest ship tracks in the world with large ship emissions along a very narrow ship track, according to the AMVER database. Moreover, the HCHO-related photochemistry would be the most active along this busy ship track because the ship track is located in a tropical region (along the latitude of $\sim 5^{\circ} \mathrm{N}$ ). Table 4 shows this active HCHO-related photochemistry. The magnitudes of the $\mathrm{HCHO}$ increases $\left(\triangle[\mathrm{HCHO}]_{\max }\right)$ in the tropical scenarios are larger than those in the other latitudinal scenarios. Also, it is expected that the peak HCHO mixing ratios along the tropical ship track would be enhanced up to $\sim 572.6 \mathrm{pptv}$ $\left(\Delta[\mathrm{HCHO}]_{\max }+\right.$ background $\mathrm{HCHO}$ mixing ratio) due to the increases in both the HCHO enhancements within the ship plumes and in the background air. The peak HCHO mixing ratios can increase even further because our background HCHO mixing ratios, shown in Table 2, were calculated simply from the UBoM $2 \mathrm{~K} 8$ Eulerian-mode modelling with relatively low background conditions, which are not affected directly by other ship emissions in the narrow ship track. The real background HCHO mixing ratios could be higher than the ones simulated in this study due to the effects of the pollutants emitted from other ships in the heavy ship traffic background (cf. von Glasow et al., 2003).

\subsection{Remaining uncertainties}

$\mathrm{CH}_{4}$ oxidation and $\mathrm{HCHO}$ production within ship plumes were examined using a ship-plume photochemical/dynamic model. Although the ship-plume model used in this study is equipped with state-of-the-art chemical schemes, aerosol micro-physics and dynamics, and heterogeneous reaction parameterizations, it does not include several HCHO-related chemical and heterogeneous processes, e.g.: (1) HCHO uptake by marine aerosols with the production of organic complexes or formic acid (e.g., Jacob et al., 1996; Kieber et al, 1999); (2) heterogeneous recycling of $\mathrm{CH}_{3} \mathrm{OH}$ to $\mathrm{HCHO}$ on the surface of marine aerosols (Jaegle et al., 2000); and (3) halogen chemistry (Sander and Crutzen, 1996; Vogt et al., 1996; Wagner et al., 2002; von Glasow et al., 2003). Heterogeneous $\mathrm{HCHO}$ uptake and recycling of $\mathrm{CH}_{3} \mathrm{OH}$ to $\mathrm{HCHO}$ were excluded because these issues are rather speculative without any concrete evidence from the field measurements. In addition, as discussed in Sect. 3.1, the formation of $\mathrm{CH}_{3} \mathrm{OH}$ would be limited at high $\mathrm{NO}_{\mathrm{x}}$ situations. Therefore, the heterogeneous recycling of $\mathrm{CH}_{3} \mathrm{OH}$ was excluded.

Halogen chemistry is often active in the MBL and could also be important in ship plumes. If halogen chemistry is active in the ship-influenced MBL, the rate of $\mathrm{CH}_{4}$ oxidation (rate of hydrogen abstract by $\mathrm{Cl}$, i.e., $\left.\mathrm{CH}_{4}+\mathrm{Cl}+\mathrm{O}_{2} \rightarrow \mathrm{CH}_{3} \mathrm{O}_{2}+\mathrm{HCl}\right)$ and the rate of the $\mathrm{CH}_{3} \mathrm{O}_{2}+\mathrm{XO} \rightarrow \mathrm{HCHO}+\mathrm{X}+\mathrm{HO}_{2}$ (where $\mathrm{X}=\mathrm{Cl}, \mathrm{Br}$, or I) reaction could be enhanced further, yielding even higher $\mathrm{HCHO}$ mixing ratios in the ship-going MBL. However, under high $\mathrm{NO}_{\mathrm{x}}$ conditions, such as ship plumes, bromine chemistry may be of limited importance as $\mathrm{BrO}$ mixing ratios might be reduced. In the early plume this can be caused by the reaction $\mathrm{NO}+\mathrm{BrO} \rightarrow \mathrm{NO}_{2}+\mathrm{Br}$ (von Glasow et al., 2003). It can also be caused by the radical termination reactions 
of $\mathrm{BrO}+\mathrm{NO}_{2} \rightarrow \mathrm{BrONO}_{2}$. On the other hand, the formation of $\mathrm{BrONO}_{2}$ can lead to an increase in the release of bromine from sea-salt aerosol as the very photolabile $\mathrm{Br}_{2}$ is released from sea-salt aerosol upon the reaction of $\mathrm{BrONO}_{2}$ on bromide containing aerosol (see discussion in Sander et al., 1999). The magnitude of reaction probability of $\mathrm{BrONO}_{2}$ on sea-salt particles $\left(\gamma_{\mathrm{BrONO}_{2}, \mathrm{SS}}\right)$ is somewhat uncertain but Sander et al. (1999) showed that this reaction can be impor-

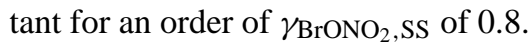

Although the efficiency of the auto-catalytic bromine release from sea-salt particles under the high $\mathrm{NO}_{\mathrm{x}}$ ship-plume conditions is somewhat uncertain and its effect on HCHO is probably limited, it is still likely that chlorine atoms play an active role in the ship-plume photochemistry, especially for the oxidation of $\mathrm{CH}_{4}$. Enhanced concentrations of chlorine in ship plumes can result from acid displacement of $\mathrm{HCl}$ from sea-salt aerosol and subsequent release of $\mathrm{Cl}$ atoms upon the reaction of $\mathrm{HCl}$ with $\mathrm{OH}$ (see e.g., Keene et al., 2007). Another pathway for chlorine release is via the reaction of dinitrogen pentoxide $\left(\mathrm{N}_{2} \mathrm{O}_{5}\right)$ on chloride containing aerosol particles, resulting in the formation of nitryl chloride $\left(\mathrm{ClNO}_{2}\right)$ which decomposes to $\mathrm{Cl}$ atoms and $\mathrm{NO}_{2}$ at daytime (Osthoff et al., 2008; von Glasow, 2008). Figure 10 shows the buildup of $\mathrm{N}_{2} \mathrm{O}_{5}$ in the ITCT $2 \mathrm{~K} 2$ base ship-plume case, even during daytime situations due to the high levels of $\mathrm{NO}_{2}$ and $\mathrm{O}_{3}$ (a detailed analysis regarding the daytime $\mathrm{N}_{2} \mathrm{O}_{5}$ formation inside the ship plumes was reported by Song et al., 2003a). At this stage, the predicted $\mathrm{N}_{2} \mathrm{O}_{5}$ concentrations have not been confirmed by measurements, so that a reliable quantification of a potential $\mathrm{Cl}$ atom source from this mechanism is difficult. The rate constant for $\mathrm{CH}_{4}+\mathrm{Cl}$ is about 17 times faster than $\mathrm{CH}_{4}+\mathrm{OH}$ (at $T=290 \mathrm{~K}$ ). In order for $\mathrm{Cl}$ atoms to contribute $10 \%$ to the oxidation of $\mathrm{CH}_{4}$ under the high $\mathrm{OH}$ conditions within the ship plumes as predicted in this study, $\mathrm{Cl}$ concentrations would have to be in the order of $6 \times 10^{5}$ (atoms $\mathrm{cm}^{-3}$ ).

\section{Summary and future studies}

Enhanced levels of formaldehyde (HCHO) along global ship corridors were observed from satellite sensors and were simulated using global 3-D CTMs in several previous studies (e.g., Hoor et al., 2009; Marbach et al., 2009). Three likely sources were investigated to identify the detailed sources of the enhanced levels of HCHO for the ITCT 2K2 ship-plume case: (1) primary HCHO emission from ships, (2) secondary $\mathrm{HCHO}$ production from NMVOCs emitted from ships, and (3) atmospheric oxidation of $\mathrm{CH}_{4}$. By carrying out multiple ship-plume model runs, it was found that $\mathrm{CH}_{4}$ oxidation via enhanced levels of $\mathrm{OH}$ radicals is mainly responsible for the elevated levels of HCHO inside the ship plumes. During $\sim 200$ min after the ship-plume release, more than $\sim 88 \%$ of the HCHO enhancements within the ship plumes was due to $\mathrm{CH}_{4}$ oxidation in the ITCT $2 \mathrm{~K} 2$ base case. However,

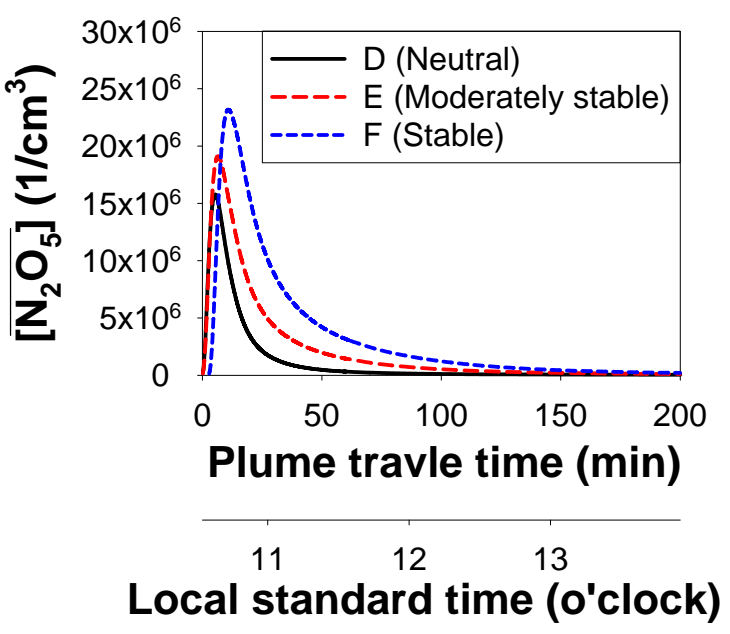

Fig. 10. Possible build-up of dinitrogen pentoxide $\left(\mathrm{N}_{2} \mathrm{O}_{5}\right)$ radicals inside the ITCT $2 \mathrm{~K} 2$ ship plume with three MBL stability classes: (i) neutral (D), (ii) moderately stable (E), and (iii) stable (F). The ship plumes are released at 10:30 a.m. LST.

this fraction of the $\mathrm{HCHO}$ enhancements from $\mathrm{CH}_{4}$ oxidation was inferred only from the base case study (with a shipplume release time at 10:30 LST). The contribution would vary in different situations.

Various likely ship-plume situations in the global ship corridors were also studied to determine the enhancements of the HCHO levels in the ship-going MBL. It was found that the ship-plume $\mathrm{HCHO}$ levels could increase up to $\sim 572.6$ pptv higher than the background HCHO levels, depending on the latitudinal location of ship plumes, $\mathrm{NO}_{\mathrm{x}}$ emission rates and the stability of the MBL.

Previous grid-based global CTM simulation studies did not simultaneously consider the ship-plume nonlinear photochemistry and turbulent dispersion in their model framework, thereby producing overestimated MBL concentrations of $\mathrm{O}_{3}$, $\mathrm{OH}$ and $\mathrm{NO}_{\mathrm{x}}$ along the global ship corridors (e.g., Lawrence and Crutzen, 1999; Hoor et al., 2009). As indicated in this study and the companion work (Kim et al., 2009), the 3D CTM simulations with sophisticated ship-plume parameterizations are important to correctly estimate the atmospheric composition within the ship-influenced MBL along the global ship corridors (e.g., refer to Huszar et al., 2010). A better estimation of the atmospheric MBL composition and processes can also be linked to many other on-going research issues. For example, as demonstrated in this study and Kim et al.'s work (2009), the enhanced OH levels inside the ship-plume results in elevated levels of $\mathrm{HCHO}$ as well as acidic substances, such as $\mathrm{HNO}_{3}$ and $\mathrm{H}_{2} \mathrm{SO}_{4}$, mainly through the oxidation of ship-emitted $\mathrm{NO}_{2}$ and $\mathrm{SO}_{2}$. Therefore, within the heavy ship-traffic MBL, the active production of $\mathrm{HNO}_{3}$ and $\mathrm{H}_{2} \mathrm{SO}_{4}$ can lead to increased formation of particulate nitrate and sulfate, both of which have a negative impact on the global radiative forcing (Hansen and Sato, 
2001; IPCC, 2007). In addition, the increased $\mathrm{H}_{2} \mathrm{SO}_{4}$ mixing ratios within the ship plumes can create favourable conditions for fresh particle formation (i.e., nucleation), which can subsequently grow into accumulation-mode particles and can often form stratocumulus clouds, known for "ship track" (e.g., Radke et al., 1989; Song et al., 2003b; Frick and Hoppel, 2000; Hobbs et al., 2000; Hudson et al., 2000; Langley et al., 2010). Furthermore, when particulate nitrate in the MBL ship corridor is dry-deposited onto the ocean surface, it can act as a fertilizer (nitrogen source) that can subsequently increase the active phytoplankton activity in the ocean (Duce et al., 1991; Prospero et al., 1996; Dentener et al., 2006; Duce et al., 2008). Overall, the immense influences of ship-plume photochemistry on atmospheric chemical cycles, global climate changes and marine biota activities as well as the complicated interactions among these changes can be investigated more accurately by incorporating the current model framework into the global CTMs.

\section{Appendix A}

In Sect. 3.1, a conceptual expression for the HCHO formation rate $\left(F_{\mathrm{HCHO}}\right)$ was introduced (see Eq. 3$)$. Actual equation used in the ship-plume model simulations is shown in Eq. (A1), based on the modified Lurmann chemical reaction mechanism (Lurmann et al., 1986):

$$
\begin{aligned}
& F_{\mathrm{HCHO}} \\
& =k_{\mathrm{CH}_{3} \mathrm{O}_{2}+\mathrm{CH}_{3} \mathrm{O}_{2}}\left[\mathrm{CH}_{3} \mathrm{O}_{2}\right]^{2} \\
& +k_{\mathrm{CH}_{3} \mathrm{OOH}+\mathrm{OH}}\left[\mathrm{CH}_{3} \mathrm{OOH}\right][\mathrm{OH}]+k_{\mathrm{CH}_{3} \mathrm{O}+\mathrm{O}_{2}}\left[\mathrm{CH}_{3} \mathrm{O}\right]\left[\mathrm{O}_{2}\right] \\
& +k_{\mathrm{CH}_{2} \mathrm{OH}+\mathrm{O}_{2}}\left[\mathrm{CH}_{2} \mathrm{OH}\right]\left[\mathrm{O}_{2}\right]+k_{\mathrm{RAN} 1+\mathrm{NO}}\left[\mathrm{RAN}_{1}\right][\mathrm{NO}] \\
& +0.5 k_{\mathrm{ISOP}+\mathrm{O}_{3}}[\mathrm{ISOP}]\left[\mathrm{O}_{3}\right]+0.9 k_{\mathrm{RIO}_{2}+\mathrm{NO}}\left[\mathrm{RIO}_{2}\right][\mathrm{NO}] \\
& +k_{\mathrm{INO}_{2}+\mathrm{NO}}\left[\mathrm{INO}_{2}\right][\mathrm{NO}]+0.5 k_{\mathrm{MVK}+\mathrm{O}_{3}}[\mathrm{MVK}]\left[\mathrm{O}_{3}\right] \\
& +0.3 k_{\mathrm{VRO}_{2}+\mathrm{NO}}\left[\mathrm{VRO}_{2}\right][\mathrm{NO}]+k_{\mathrm{MVN}_{2}+N o}\left[\mathrm{MVN}_{2}\right][\mathrm{NO}] \\
& +0.65 k_{\mathrm{MACR}+\mathrm{O}_{3}}[\mathrm{MACR}]\left[\mathrm{O}_{3}\right]+k_{\mathrm{MAN}_{2}+\mathrm{NO}}\left[\mathrm{MAN}_{2}\right][\mathrm{NO}] \\
& +k_{\mathrm{ETHE}+\mathrm{O}_{3}}[\mathrm{ETHE}]\left[\mathrm{O}_{3}\right]+2 k_{\mathrm{EO}_{2}+\mathrm{NO}}\left[\mathrm{EO}_{2}\right][\mathrm{NO}]
\end{aligned}
$$

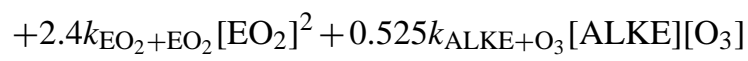

$$
\begin{aligned}
& +k_{\mathrm{PO}_{2}+\mathrm{NO}}\left[\mathrm{PO}_{2}\right][\mathrm{NO}]+k_{\mathrm{PRN}_{1}+\mathrm{NO}}\left[\mathrm{PRN}_{1}\right][\mathrm{NO}] \\
& +k_{\mathrm{CHO}_{2}+\mathrm{NO}}\left[\mathrm{CHO}_{2}\right][\mathrm{NO}]+k_{\mathrm{CHO}_{2}+\mathrm{NO}_{2}}\left[\mathrm{CHO}_{2}\right]\left[\mathrm{NO}_{2}\right] \\
& +k_{\mathrm{CHO}_{2}+\mathrm{SO}_{2}}\left[\mathrm{CHO}_{2}\right]\left[\mathrm{SO}_{2}\right]+k_{\mathrm{MCO}_{3}+\mathrm{CH}_{3} \mathrm{O}_{2}}\left[\mathrm{MCO}_{3}\right]\left[\mathrm{CH}_{3} \mathrm{O}_{2}\right] \\
& +k_{\mathrm{MCO}_{3}+\mathrm{CH}_{3} \mathrm{O}_{2}}\left[\mathrm{MCO}_{3}\right]\left[\mathrm{CH}_{3} \mathrm{O}_{2}\right]+J_{\mathrm{MCP}}[\mathrm{MCP}] \\
& +0.5 k_{\mathrm{MCP}+\mathrm{OH}}[\mathrm{MCP}][\mathrm{OH}]+k_{\mathrm{EP}+\mathrm{OH}}[\mathrm{EP}][\mathrm{OH}]+2 J_{\mathrm{EP}}[\mathrm{EP}] \\
& +k_{\mathrm{HACO}+\mathrm{NO}}[\mathrm{HACO}][\mathrm{NO}]+k_{\mathrm{HEP}+\mathrm{OH}}[\mathrm{HEP}][\mathrm{OH}] \\
& +2 J_{\mathrm{HEP}}[\mathrm{HEP}]
\end{aligned}
$$

where, $k_{x+y}$ represents the rate constant $\left(\mathrm{cm}^{3}\right.$ molecules $s^{-1} \mathrm{~s}^{-1}$ ) for thermal reactions between atmospheric species $\mathrm{X}$ and $\mathrm{Y}$, and $J_{z}$ is the rate constant $\left(\mathrm{s}^{-1}\right)$ for photolytic dissociation reactions of atmospheric species Z. The abbreviations of atmospheric species in Eq. (A1) are as follows: $\mathrm{RAN}_{1}$ (Alkane $\mathrm{RNO}_{2}$ ); ISOP (Isoprene); $\mathrm{RIO}_{2}$ (Isoprene $\mathrm{RNO}_{2}$ ); $\mathrm{INO}_{2}$ (Isoprene $\mathrm{NO}_{3}-\mathrm{O}_{2}$ adduct); MVK (Methyl Vinyl Ketone); $\mathrm{VRO}_{2}\left(\mathrm{MVK} \mathrm{RNO}_{2}\right) ; \mathrm{MVN}_{2}$ $\left(\mathrm{MVK}+\mathrm{NO}_{3}\right.$ radical adduct); MACR (Methacrolein); $\mathrm{MAN}_{2}$ $\left(\mathrm{MACR}+\mathrm{NO}_{3}\right.$ radical product); ETHE (Ethene); $\mathrm{EO}_{2}$ (Ethene $\mathrm{RO}_{2}$ ); ALKE ( $\geq$ alkenes); $\mathrm{PO}_{2}$ (Higher alkenes $\mathrm{RO}_{2}$ ); $\mathrm{PRN}_{1}$ (Alkenes $+\mathrm{NO}_{3}$ radical product); $\mathrm{MCO}_{3}$ $\left(\mathrm{CH}_{3} \mathrm{CO}_{3}\right)$; $\mathrm{MCP}\left(\mathrm{CH}_{3} \mathrm{C}(\mathrm{O}) \mathrm{COOH}\right)$; EP $\left(\mathrm{HOC}_{2} \mathrm{H}_{4} \mathrm{OOH}\right)$; $\mathrm{HACO}\left(\mathrm{HOCH}_{2} \mathrm{C}(\mathrm{O}) \mathrm{OO}\right)$; and $\mathrm{HEP}\left(\mathrm{HACO}+\mathrm{HO}_{2}\right.$ radical product).

Acknowledgements. This study was financially supported by Mid-Career Research Programme through the National Research Foundation of Korea (NRF) grant from the Ministry of Education, Science and Technology (MEST) (2010-0014058) as well as by Basic Research Project provided by Gwangju Institute of Science and Technology (GIST), 2010. This study was performed, when C. H. Song was on his sabbatical leave at the School of Environmental Sciences at the University of East Anglia (UEA), UK. All the ITCT 2K2 airborne datasets in this study were obtained from the official NOAA data archive at http://esrl.noaa.gov/csd/ tropchem/2002ITCT/P3/DataDownload/index.php.

Edited by: P. Jöckel

\section{References}

Arnold, S. R., Spracklen, D. V., Williams, J., Yassaa, N., Sciare, J., Bonsang, B., Gros, V., Peeken, I., Lewis, A. C., Alvain, S., and Moulin, C.: Evaluation of the global oceanic isoprene source and its impacts on marine organic carbon aerosol, Atmos. Chem. Phys., 9, 1253-1262, doi:10.5194/acp-9-1253-2009, 2009.

Bey, I., Jacob, D. J., Yantosca, R. M., Logan, J. A., Field, B. D., Fiore, A. M., Li, Q., Liu, H. Y., Mickley, L. J., and Schultz, M. G.: Global modeling of tropospheric chemistry with assimilated meteorology: Model description and evaluation, J. Geophys. Res., 106, 23073-23096, 2001.

Buhaug, Ø., Corbett, J. J. , Endresen, Ø., Eyring, V., Faber, J., Hanayama S., Lee, D. S., Lee, D., Lindstad, H., Markowska, A. Z., Mjelde, A., Nelissen, D., Nilsen, J., Pålsson, C., Winebrake, J. J., Wu, W.-Q., and Yoshida, K.: Second IMO GHG study 2009, International Maritime Organization (IMO), London, UK, available at: http: //www.imo.org/OurWork/Environment/PollutionPrevention/ AirPollution/Pages/Greenhouse-Gas-Study-2009.aspx, March 2009.

Capaldo, K., Corbett, J. J., Kasibhatla, P., Fischbeck, P., and Pandis, S. N.: Effects of ship emissions on sulphur cycling and radiative climate forcing over the ocean, Nature, 400, 743-746, 1999.

Chen, G., Huey, L. G., Trainer, M., Nicks, D., Corbett, J., Ryerson, T., Parrish, D., Neuman, J. A., Nowak, J., Tanner, D., Holloway, J., Brock, C., Crawford, J., Olson, J. R., Sullivan, A., Weber, R., Schauffler, S., Donnelly, S., Atlas, E., Roberts, J., Flocke, F., Hübler, G., and Fehsenfeld, F.: An investigation of the chemistry of ship emission plumes during ITCT 2002, J. Geophys. Res., 110, D10S90, doi:10.1029/2004JD005236, 2005.

Chin, M., Rood, R. B., Lin, S.-J., Müller, J.-F., and Thompson, A. M.: Atmospheric sulfur cycle simulated in the global model 
GOCART: Model description and global properties, J. Geophys. Res., 110(D20), 24671-24687, 2000.

Cooper, D. A., Peterson, K., and Simpson, D.: Hydrocarbon, PAH and PCB emissions from ferries: A case study in the SkagerakKattegatt-Öresund region, Atmos. Environ., 30(14), 2463-2473, 1996.

Corbett, J. J. and Fischbeck, P.: Emissions from ships, Science, 278, 823-824, 1997.

Corbett, J. J. and Koehler, H. W.: Updated emissions from ocean shipping, J. Geophys. Res., 108(D20), 4650, doi:10.1029/2003JD003751, 2003.

Corbett, J. J., Fischbeck, P. S., and Pandis, S. N.: Global nitrogen and sulfur inventories for oceangoing ships, J. Geophys. Res., 104(D3), 3457-3470, 1999.

de Gouw, J. A., Warneke, C., Scheeren, H. A., van der Veen, C., Bolder, M., Scheele, M. P., Williams, J., Wong, S., Lange, L., Fischer, H., and Lelieveld, J.: Overview of the trace gas measurements on board the Citation aircraft during the intensive field phase of INDOEX, J. Geophys. Res., 106(D22), 28453-28467, 2001.

Dentener, F., Drevet, J., Lamarque, J. F., Bey, I., Eickhout, B., Fiore, A. M., Hauglustaine, D., Horowitz, L. W., Krol, M., Kulshrestha, U. C., Lawrence, M., Glay-Lacaux, C., Rast, S., Shindell, D., Stevenson, D., Van Noije, T., Atherton, C., Bell, N., Bergman, D., Butler, T., Cofala, J., Collins, B., Doherty, R., Ellingsen, K., Galloway, J., Gauss, M., Montanaro, V., Müller, J. F., Pitari, G., Rodriguez, J., Sanderson, M., Solmon, F., Strahan, S., Schultz, S., Sudo, M., Szopa, S., and Wild, O.: Nitrogen and sulfur deposition on regional and global scales: A multimodel evaluation, Global Biogeochem. Cy., 20, GB4003, doi:10.1029/2005GB002672, 2006.

Duce, R. A., Liss, P. S., Merrill, J. T., Atlas, E. L., Buat-Menard, P., Hicks, B. B., Miller, J. M., Prospero, J. M., Arimoto, R., Church, T. M., Ellis, W., Galloway, J. N., Hansen, L., Jickells, T. D., Knap, A. H., Reinhardt, K. H., Schneider, B., Soudine, A., Tokos, J. J., Tsunogai, S., Wollast, R., and Zhou, M.: The atmospheric input of trace species to the world ocean, Global Biogeochem. Cy., 5(3), 193-259, 1991.

Duce, R. A., LaRoche, J., Altieri, K., Arrigo, K. R., Baker, A. R., Capone, D. G., Cornell, S., Dentener, F., Galloway, J., Ganeshram, R. S., Geider, R. J., Jickells, T., Kuypers, M. M., Langlois, R., Liss, P. S., Liu, S. M., Middelburg, J. J., Moore, C. M., Nickovic, S., Oschlies, A., Pedersen, T., Prospero, J., Schlitzer, R., Seitzinger, S., Sorensen, L. L., Uematsu, M., Ulloa, O., Voss, M., Ward, B., and Zamora, L.: Impacts of atmospheric anthropogenic nitrogen on the open ocean, Science, 320, 893-897, 2008.

Endresen, Ø., Sørgård, E., Sundet, J. K., Dalsøren, S. B., Isaksen, I. S. A., Berglen, T. F., and Gravir, G.: Emission from international sea transportation and environmental impact, J. Geophys. Res., 108(D17), 4560, doi:10.1029/2002JD002898, 2003.

European Commission Directorate General Environment and Entec UK Ltd.: Service Contract on Ship Emissions: Assignment, Abatement and Market-based Instruments. Task 1-Preliminary Assignment of Ship Emissions to European Countries, London, 2005.

EPA, Analysis of Commercial Marine Vessels Emissions and Fuel Consumption Data, Technical Report EPA 420-R-00-002, US EPA, 2000.
Eyring, V., Stevenson, D. S., Lauer, A., Dentener, F. J., Butler, T., Collins, W. J., Ellingsen, K., Gauss, M., Hauglustaine, D. A., Isaksen, I. S. A., Lawrence, M. G., Richter, A., Rodriguez, J. M., Sanderson, M., Strahan, S. E., Sudo, K., Szopa, S., van Noije, T. P. C., and Wild, O.: Multi-model simulations of the impact of international shipping on Atmospheric Chemistry and Climate in 2000 and 2030, Atmos. Chem. Phys., 7, 757-780, doi:10.5194/acp-7-757-2007, 2007.

Faloona, I.: Sulfur processing in the marine atmospheric boundary layer: A review and critical assessment of modeling uncertainties, Atmos. Environ., 43, 2841-2854, 2009.

Finlayson-Pitts, B. J. and Pitts Jr., J. N.: Chemistry of the Upper and Lower Atmosphere: Theory, Experiment, and Applications, Academic Press, San Diego, California, USA, 2000.

Frick, G. M. and Hoppel, W. A.: Airship measurements of ship's exhaust plumes and their effect on marine boundary layer clouds, J. Atmos. Sci., 57, 2625-2648, 2000.

Hanna, S. R., Schulman, L. L., Paine, R. J., Pleim, J. E., and Baer, M.: Development and evaluation of the offshore and coastal dispersion model, J. Air Pollut. Control Assoc., 35, 1039-1047, 1985.

Hansen, J. E. and Sato, M.: Trends of measured climate forcing agents, P. Natl Acad. Sci., 98(26), 14778-14783, 2001.

Hobbs, P. V., Garrett, T. J., Ferek, R. J., Strader, S. R., Hegg, D. A., Frick, G. M., Hoppel, W. A., Gasparovic, R. F., Russell, L. M., Johnson, D. W., O’Dowd, C., Durkee, P. A., Nielsen, K. E., and Innis, G.: Emissions from ships with respect to their effects on clouds, J. Atmos. Sci., 57, 2570-2590, 2000.

Houyoux, M.: Clean Air Interstate Rule Emissions Inventory Technical Support Document, US EPA, 2005.

Hoor, P., Borken-Kleefeld, J., Caro, D., Dessens, O., Endresen, O., Gauss, M., Grewe, V., Hauglustaine, D., Isaksen, I. S. A., Jöckel, P., Lelieveld, J., Myhre, G., Meijer, E., Olivie, D., Prather, M., Schnadt Poberaj, C., Shine, K. P., Staehelin, J., Tang, Q., van Aardenne, J., van Velthoven, P., and Sausen, R.: The impact of traffic emissions on atmospheric ozone and $\mathrm{OH}$ : results from QUANTIFY, Atmos. Chem. Phys., 9, 3113-3136, doi:10.5194/acp-9-3113-2009, 2009.

Hudson, J. G., Garrett, T. J., Hobbs, P. V., Strader, S. R., Xie, Y., and Yum, S. S.: Cloud condensation nuclei and ship tracks, J. Atmos. Sci., 57, 2696-2706, 2000.

Huszar, P., Cariolle, D., Paoli, R., Halenka, T., Belda, M., Schlager, H., Miksovsky, J., and Pisoft, P.: Modeling the regional impact of ship emissions on NOx and ozone levels over the Eastern Atlantic and Western Europe using ship plume parameterization, Atmos. Chem. Phys., 10, 6645-6660, doi:10.5194/acp-10-66452010, 2010.

Intergovernmental Panel on Climate Change (IPCC): Climate Change 2007: The Physical Science Basis, the Fourth Assessment Report of the IPCC, ISBN 9780521 88009-1, 2007.

Jacob, D. J., Heikes, B. G., Fan, S. M., Logan, J. A., Mauzerall, D. L., Bradshaw, J. D., Singh, H. B., Gregory, G. L., Talbot, R. W., Blake, D. R., and Sachse, G. W.: Origin of ozone and $\mathrm{NO}_{\mathrm{x}}$ in the tropical troposphere: A photochemical analysis of aircraft observations over South Atlantic basin, J. Geophys Res., 101, 24235-24250, 1996.

Jaenicke, R.: Aerosol cloud climate interaction, Tropospheric aerosols, edited by: Hobbs, P. V., Academic Press, San Diego, California, USA, 1-31, 1993. 
Jaeglé, L., Jacob, D. J., Brune, W. H., Faloona, I., Tan, D., Heikes, B. G., Kondo, Y., Sachse, G. W., Anderson, B., Gregory, G. L., Singh, H. B., Pueschel, R., Ferry, G., Blake, D. R., and Schetter, R. E.: Photochemistry of $\mathrm{HO}_{\mathrm{x}}$ in the upper troposphere at the northern midlatitudes, J. Geophys. Res., 105, 3877-3892, 2000.

Kamra, A. K., Murugavel, P., Pawar, S. D., and Gopalakrishnan, V.: Background aerosol concentration derived from the atmospheric electric conductivity measurements made over the Indian Ocean during INDOEX, J. Geophys. Res., 106(D22), 2864328651, 2001.

Karlsdóttir, S. and Isaksen, I. S. A.: Changing methane lifetime: Possible cause for reduced growth, Geophys. Res. Lett., 27(1), 93-96, 2000.

Kasibhatla, P., Levy II, H., Moxim, W. J., Pandis, S. N., Corbett, J. J., Peterson, M. C., Honrath, R. E., Frost, G. J., Knapp, K., Parrish, D. D., and Ryerson, T. B.: Do emissions from ship have a significant impact on concentrations of nitrogen oxides in the marine boundary layer?, Geophys. Res. Lett., 27, 2229-2232, 2000.

Keene, W. C., Stutz, J., Pszenny, A. A. P., Maben, J. R., Fischer, E. V., Smith, A. M. von Glasow, R., Pechtl, S., Sive, B. C., and Varner, R. K.: Inorganic chlorine and bromine in coastal New England air during summer, J. Geophys. Res., 112, D10S12, doi:10.1029/2006JD007689, 2007

Kieber, R. J., Rhines, M. F., Willey, J. D., and Avery Jr., G. B.: Rainwater formaldehyde: Concentration, deposition, and photochemical formation, Atmos. Environ., 33, 3659-3667, 1999.

Kim, H. S., Song, C. H., Park, R. S., Huey, G., and Ryu, J. Y.: Investigation of ship-plume chemistry using a newly-developed photochemical/dynamic ship-plume model, Atmos. Chem. Phys., 9, 7531-7550, doi:10.5194/acp-9-7531-2009, 2009.

Langley, L., Leaitch, W. R., Lohmann, U., Shantz, N. C., and Worsnop, D. R.: Contributions from DMS and ship emissions to $\mathrm{CCN}$ observed over the summertime North Pacific, Atmos. Chem. Phys., 10, 1287-1314, doi:10.5194/acp-10-1287-2010, 2010.

Lawrence, M. G. and Crutzen, P. J.: Influence of $\mathrm{NO}_{\mathrm{x}}$ emissions from ships on tropospheric photochemistry and climate, Nature, 402, 167-170, 1999.

Lawrence, M. G., Jöckel, P., and von Kuhlmann, R.: What does the global mean $\mathrm{OH}$ concentration tell us?, Atmos. Chem. Phys., 1, 37-49, doi:10.5194/acp-1-37-2001, 2001.

Lloyd's Register: Marine Exhaust Emissions Research Programme, Lloyd's Register Eng. Serv., London, 1995

Lurmann, F. W., Lloyd, A. C., and Atkinson, R.: A chemical mechanism for use in long-range transport/acid deposition computer modeling, J. Geophys. Res., 91(D10), 10905-10936, 1986.

Marbach, T., Beirle, S., Platt, U., Hoor, P., Wittrock, F., Richter, A., Vrekoussis, M., Grzegorski, M., Burrows, J. P., and Wagner, T.: Satellite measurements of formaldehyde linked to shipping emissions, Atmos. Chem. Phys., 9, 8223-8234, doi:10.5194/acp9-8223-2009, 2009.

Osthoff, H. D., Roberts, J. M., Ravishankara, A. R., Williams, E. J., Lerner, B. M., Sommariva, R., Bates, T. S., Coffman, D., Quinn, P. K., Dibb, J. E., Stark, H., Burkholder, J. B., Talukdar, P. K., Meagher, J., Fehsenfeld, F. C., and Brown, S. S.:: High levels of nitryl chloride in the polluted subtropical marine boundary layer, Nature Geosci. 1, 324-328, 2008.
Parrish, D. D., Kondo, Y., Cooper, O. R., Brock, C. A., Jaffe, D. A., Trainer, M., Ogawa, T., Hübler, G., and Fehsenfeld, F. C.: Intercontinental Transport and Chemical Transformation 2002 (ITCT 2K2) and Pacific Exploration of Asian Continental Emission (PEACE) experiments: An overview of the 2002 winter and spring intensives, J. Geophys. Res., 109, D23S01, doi:10.1029/2004JD004980, 2004.

Prospero, J. M., Barrett, K., Church, T., Dentener, F., Duce, R. A., Galloway, J. N., Levy II, H., Moody, J., and Quinn, P.: Atmospheric deposition of nutrients to the North Atlantic Basin, Biogeochemistry, 35(1), 27-73, 1996.

Radke, L. F., Coakley Jr., J. A., and King, M. D.: Direct and remote sensing observations of the effects of ships on clouds, Science, 246, 1146-1149, 1989.

Sander, R. and Crutzen, P. J.: Model study indicating halogen activation and ozone destruction in polluted air masses transported to the sea, J. Geophys. Res., 101(D4), 9121-9138, 1996.

Sander, R., Rudich, Y., von Glasow, R., and Crutzen, P. J.: The role of $\mathrm{BrNO}_{3}$ in marine tropospheric chemistry: A model study, Geophys. Res. Lett., 26, 2857-2860, 1999.

Song, C. H., Chen, G., Hanna, S. R., Crawford, J., and Davis, D. D.: Dispersion and chemical evolution of ship plumes in the marine boundary layer: Investigation of $\mathrm{O}_{3} / \mathrm{NO}_{\mathrm{y}} / \mathrm{HO}_{\mathrm{x}}$ chemistry, J. Geophys. Res., 108(D4), 4143, doi:10.1029/2002JD002216, 2003a.

Song, C. H., Chen, G., and Davis, D. D.: Chemical evolution and dispersion of ship plumes in the remote marine boundary layer: Investigation of sulfur chemistry, Atmos. Environ., 37, 26632679, 2003 b.

Song, C. H., Han, K. M., Cho, H. J., Kim, J., Carmichael, G. R., Kurata, G., Thongboonchoo, N., He, Z., and Kim, H. S.: A Lagrangian model investigation of chemico-microphysical evolution of northeast Asian pollution plumes within the MBL during Trace-P, Atmos. Environ., 41, 8932-8951, 2007.

Tuan, M. D.: Eulerian photochemical box modeling for investigating secondary inorganic formation over the greater Seoul area, MS thesis, GIST, Gwangju, 2008.

Xuan, N. T.: Measured and modeled ozone production efficiency along the Pacific coast of North America, MS thesis, GIST, Gwangju, 2009.

Vogt, R., Crutzen, P. J., and Sander, R.: A mechanism for halogen release from sea-salt aerosol in the remote marine boundary layer, Nature, 383, 327-330, 1996.

von Glasow, R., Lawrence, M. G., Sander, R., and Crutzen, P. J.: Modeling the chemical effects of ship exhaust in the cloudfree marine boundary layer, Atmos. Chem. Phys., 3, 233-250, doi:10.5194/acp-3-233-2003, 2003.

Von Glasow, R.: Pollution meets sea-salt, Nature Geosci., 1, 292293, 2008.

Wagner V., Schiller, C., and Fischer, H.: Formaldehyde measurements in the marine boundary layer of the Indian Ocean during the 1999 INDOEX cruise of the R/V Ronald H. Brown, J. Geophys. Res., 106, 28529-28538, 2001.

Wagner, V., von Glasow, R., Fischer, H., and Crutzen, P. J.: Are $\mathrm{CH}_{2} \mathrm{O}$ measurements in the marine boundary layer suitable for testing the current understanding of the $\mathrm{CH}_{4}$ photooxidation?: A model study, J. Geophys. Res., 107(D3), 4029, doi:10.1029/2001JD000722, 2002. 